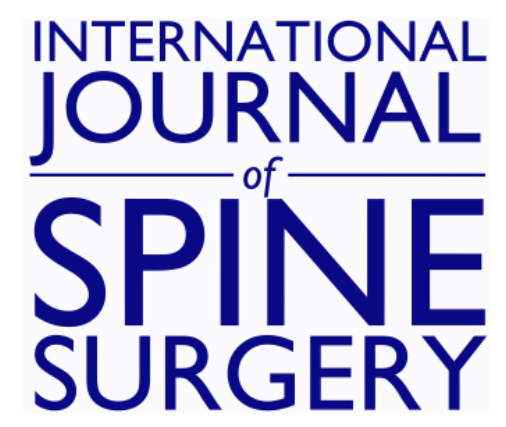

\title{
ISASS Recommendations/Coverage Criteria for Decompression with Interlaminar Stabilization - Coverage Indications, Limitations, and/or Medical Necessity
}

Richard Guyer, Michael Musacchio, Frank P. Cammisa, Jr. and Morgan P. Lorio

Int J Spine Surg 2016, 10 ()

doi: https://doi.org/10.14444/3041

http://ijssurgery.com/content/10/41

This information is current as of April 26, 2023.

Email Alerts Receive free email-alerts when new articles cite this article. Sign up at:

http://ijssurgery.com/alerts

The International Journal of Sphine Surgerbittp://ijssurgery.com/ by guest on April 26, 2 2397 Waterbury Circle, Suite 1,

Aurora, IL 60504, Phone: +1-630-375-1432

(C) 2016 ISASS. All Rights Reserved. 


\section{ISASS Recommendations/Coverage Criteria for Decompression with Interlaminar Stabilization - Coverage Indications, Limitations, and/or Medical Necessity}

Richard Guyer, MD,1 Michael Musacchio, MD,2 Frank P. Cammisa, Jr., MD, ${ }^{3}$ Morgan P. Lorio, MD, FACS 4

${ }^{1}$ Texas Back Institute, Plano, $T X^{2}$ Center for Spine Care, Dallas, TX, ${ }^{3}$ Hospital for Special Surgery, New York, New York, ${ }^{4}$ NeuroSpine Solutions, Bristol, $T N$

KEYWORDS: DECOMPRESSION, INTERLAMINAR STABILIZATION (ILS), LUMBAR SPINAL STENOSIS (LSS)

VOLUME 10 ARTICLE 41 DOI: 10.14444/3041

\section{Introduction}

Broadly defined, lumbar spinal stenosis (LSS) is the progressive narrowing of the spinal canal and neural foramen resulting in pressure upon the nerve(s) leading to pain and/or numbness in the extremities, muscle weakness, bowel and bladder issues, and/or other pain related issues. However, the difficulty arises in that spinal stenosis is a heterogeneous condition with multiple etiologies which may present with disc height loss, facet hypertrophy, spondylolisthesis, retrolisthesis, coronal and/or sagittal plane deformity, and presence of osteophytes and facet cysts. Therefore, there is not a single surgical intervention that addresses all pathological variations of spinal stenosis, rather, there are several methods used to treat LSS. Diagnostic evaluation is needed to determine the correct surgical treatment solution to address anatomical and pathological variation as some patients can be treated by simple decompression while others may require a form of stabilization. This policy statement focuses on one treatment option: decompression with interlaminar stabilization.

ISASS does not recommend any particular treatment method; the choice of treatment depends on the patient's pathology and the expertise of the treating surgeon. ISASS recommends shared decisionmaking between the patient and the surgeon.

Due to a growing elderly population, there is a rising incidence of LSS and varying options of therapeutic pathways. The majority of patients diagnosed with LSS are initially managed conservatively with epidural steroid injections, physical therapy, and modification of activities of daily life. However, several studies have demonstrated that if there is no significant improvement in symptoms after 12 weeks of conservative treatment, generally, symptoms do not improve with time. ${ }^{1,2}$ Patients with a diagnosis of LSS who do not experience leg and/or back pain symptom relief from conservative care management and who experience continued worsening of symptoms may be appropriate candidates for surgical treatment. Surgical treatment options include indirect decompression with interspinous distraction devices, direct surgical decompression, direct surgical decompression with interlaminar stabilization, and direct surgical decompression with fusion.

For mild spinal stenosis (or early-stage disease), an interspinous distraction device without an associated concomitant bony decompression may be considered as an alternative option to a decompression-alone procedure. The X-STOP (Medtronic, Memphis, TN) was approved by the FDA in $2006,{ }^{3}$ however Medtronic removed the technology from the market in 2015. At present, the only non-fusion interspinous distraction device available in the United States is the Superion (VertiFlex, San Clemente, CA). Superion has been CE marked since 2007 and following a clinical study of 470 patients, the FDA approved the device for use on May 20, 2015. ${ }^{4}$ The data was sufficient for approval of a Category I CPT code effective January 1, 2017. This ISASS policy does not formally address coverage rationale for interspinous distraction devices without decompression pending further data and review of this type of procedural approach in treating LSS.

For patients with mild to moderate stenosis and no instability (absence of spondylolisthesis or presence of a stable spondylolisthesis) direct open or microsurgical decompression of the offending bony and soft tissue pathology is a widely-accepted and com- 
monly performed surgical treatment solution. ${ }^{5}$ Direct surgical decompression may occasionally lead to instability (caused by continued degenerative processes, excessive facet resection, excess stress on remaining supporting structures, or natural history of LSS disease) which may result in recurrence of stenosis and leg and back pain. In order to achieve satisfactory results, adequate neural decompression and surgical excision of bone and soft tissue causing the stenosis should be the primary goal of surgery. ${ }^{5}$ There have been several studies comparing medical/interventional management to surgical decompression that have consistently shown that surgical decompression patients report both significantly better short-term and long-term improvement compared to medical management. In SPORT, Weinstein et al. ${ }^{6,7}$ performed concurrent lumbar spinal stenosis prospective studies with a randomized and an observational cohort to study decompression compared to conservative care. At four years follow-up, $60 \%$ of decompression alone patients maintained a 15-point improvement in the Oswestry Disability Index (ODI) with a $28 \%$ treatment effect over medical management, which was statistically significant. In the decompression group, the re-operation rate ranged from $8 \%$ at two years to $13 \%$ at four years where $6 \%$ was due to recurrent stenosis. However, Modhia ${ }^{5}$ reviewed the Medicare database over a four-year period and showed readmission rates of 8 to $10 \%$ per year after failed microsurgical decompression for treatment of lumbar spinal stenosis resulting in injections for pain management, revision decompression, or conversion to fusion. Forsth et al. ${ }^{8}$ recently published a prospective, randomized study examining LSS patients with and without degenerative spondylolisthesis. Patients were divided into two treatment groups: decompression alone or decompression plus fusion. The results show no clinical differences between the groups at five years follow-up, but $21 \%$ of patients in the decompression alone group required revision surgery by a mean of 6.5 years follow up. Further, Ghogawala et al. prospectively studied patients with LSS and a stable spondylolisthesis and found a cumulative reoperation rate of $34 \%$ in the decompression alone group. ${ }^{9}$

Pedicle screw fusion is the standard of care treatment for patients with spinal stenosis with significant in- stability (unstable spondylolisthesis) and concomitant debilitating back pain often associated with sagittal and coronal plane deformity. The addition of instrumentation and fusion to provide a clinically meaningful difference compared to decompression alone in prospective, randomized studies with spondylolisthesis has been established when nonspondylolisthesis patients are within the cohort. Recent findings comparing decompression alone to decompression plus fusion are inconsistent relative to clinical outcomes providing greater improvement over decompression alone. ${ }^{8,9}$ Forsth et al. showed significant differences in peri-operative outcomes favoring decompression alone, but no difference in clinical outcomes out to five years follow-up between decompression alone and decompression plus fusion in patients in a mixed patient cohort with and without spondylolisthesis. ${ }^{8}$ However, Ghogawala et al. found in patients with Grade 1 spondylolisthesis a greater improvement in SF-36 physical component and ODI at 4 years follow-up that was statistically significant over decompression alone. ${ }^{9}$ Both studies however still showed clinically significant reoperation rates in the fusion group, $22 \%$ and $14 \%$ respectively, but with even higher reoperation rates in the decompression alone cohort. ${ }^{8,9}$

There exists a population of patients who present with moderate to severe stenosis, with concomitant back pain, where decompression alone does not adequately address back pain. Weinstein ${ }^{6}$ and Kleinstück $^{10}$ suggest that those patients with predominant back pain or facetogenic issues may benefit from stabilization. Interlaminar stabilization after direct decompression is a non-fusion surgical option that can provide the additional stability over decompression alone without the rigidity of an instrumented fusion. Currently, there is one product that has achieved FDA PMA approval for up to a Grade I spondylolisthesis, the coflex (Paradigm Spine, New York, NY). The findings from Kumar ${ }^{11}$ comparing decompression alone and decompression with interlaminar stabilization, combined with the publication from Musacchio $^{12}$ comparing five-year outcomes of decompression with interlaminar stabilization and decompression plus fusion, provide compelling evidence supporting this as a treatment alternative for select patients with stenosis. Studies have shown that a non- 
fusion interlaminar stabilization device maintains motion, reduces both leg and back pain, and preserves foraminal height. ${ }^{12}$ Further, the studies have also shown clinical benefit for patients with and without spondylolisthesis.

\section{Coverage Rationale for}

\section{Decompression with}

\section{Interlaminar Stabilization}

For the majority of spinal procedures, the addition of hardware instrumentation has offered the ability to improve effectiveness and sustainability by providing immediate stability. In some cases, a decompression procedure in of itself may create iatrogenic instability, compromising the structural integrity of the posterior elements. Important consideration should be given to the amount and degree of relative facetdriven back pain, presence and grade of spondylolisthesis/retrolisthesis, osteophytes and relative loss of disc height. In stenosis patients where a direct surgical decompression has been deemed medically necessary by the surgeon, and the patient does not present with gross instability (>Grade 1), non-fusion interlaminar stabilization can provide controlled reliable motion. The positioning between the lamina allows the physiological load to be offset from the facet joints, provides direct neurological decompression, and reestablishes the foraminal height.

Two prospective, randomized, multi-center, controlled, Level 1 clinical studies have been conducted to understand the sustainability and durability of decompression (D) with interlaminar stabilization (ILS). Raushmann et al. ${ }^{13}$ have recently completed a prospective, randomized, multi-center Level 1 clinical trial comparing decompression alone (DA) to D+ILS at 24-months in a 1:1 randomization of 230 patients. Patients must have failed 3 months of conservative treatment, be greater than 40 years old, report Visual Analog Scale (VAS) back pain $\geq 50$, and have radiographically confirmed degenerative spinal stenosis. The primary clinical outcome success (no reoperations, revisions, or injections) was achieved in 82.7\% (91/110) of the D+ILS patients compared to $73 \%(84 / 115)$ of the DA patients, trending towards statistical significance $(\mathrm{p}=0.081)$. Within the primary outcome, there was a statistically significant difference between the treatments with regard to no lumbar injections where $95.5 \%$ (105/110) of the D+ILS patients compared to $87 \%(100 / 115)$ of the DA patients achieved success $(p=0.025)$. The clinical composite success (CCS) was defined as the primary outcome success and an ODI improvement of at least 15 points. The CCS was achieved in $61.4 \%$ in the D+ILS group compared to $49 \%$ in the DA group, trending towards statistical significance $(\mathrm{p}=0.076)$. Of the CCS patients, the additional component of no narcotics usage showed a statistically significant difference ( $\mathrm{p}=0.021$ ) between D+ILS (58.4\%) compared to DA (42.2\%), and with the further addition of neurological success (no new or increasing neurological deficit), the statistically significant difference becomes more significant with $55.4 \%$ of D+ILS compared to $36.3 \% \mathrm{DA}(\mathrm{p}=0.006)$. Finally, as spinal stenosis is most often related to leg pain, the CCS combined with VAS leg pain success showed a statistically significant difference with $69.3 \%$ of the D+ILS group compared to $59.2 \%$ of the DA group $(\mathrm{p}=$ 0.017 ). This study provides strong evidence showing the addition of interlaminar stabilization to a decompression procedure has significant advantages in quality of life and durability components for select patients within the LSS continuum.

The United States IDE trial compared decompression plus fusion (DF) to D+ILS for the treatment of moderate to severe lumbar spinal stenosis (47\% with a spondylolisthesis and 53\% without the presence of a spondylolisthesis), where 322 patients (215 D+ILS /107 DF, respectively) were followed through five years. ${ }^{12}$ Clinical outcomes measurements were gathered annually: ODI, leg and back pain VAS, and Zurich Claudication Questionnaire (ZCQ). At the five year follow-up, Musacchio et al. ${ }^{12}$ reported over 99\% of D+ILS patients achieved pain improvement of at least $20 \mathrm{~mm}$ in VAS leg pain and over $80 \%$ achieved at least 15-point improvement in ODI. By all patient-derived parameters, the treatments were found equivalent, however a higher percentage of D+ILS patients at all follow-up time points achieved at least 15-point improvement in ODI, and at least 20 $\mathrm{mm}$ VAS leg pain and VAS back pain improvement compared to the DF group. The percentage of pa- 
tients achieving a clinical improvement of at least 15-points in ODI at three months post operatively was $87 \%$ for D+ILS and 74\% for DF. Leg pain was immediately and sustainably relieved in both patient groups evidenced by VAS Leg and ZCQ measurements. For the D+ILS group, VAS Leg scores were 76 preoperatively, and 23 at 60 months; for the DF group, VAS Leg scores were 78 preoperatively, and 25 at 60 months. ZCQ (Physical Function) scores in the D+ILS group were 2.8 preoperatively, and 1.7 at 60 months, while ZCQ scores for DF were 2.8 preoperatively, and 1.8 at 60 months. Furthermore, back pain was also immediately and sustainably relieved through facet off-loading in the D+ILS group, with VAS Back scores of 80 preoperatively, and 25 at 60 months. VAS Back scores for DF were 79 preoperatively, and 29 at 60 months.

In terms of reoperations/revisions, the results of Musacchio et al. ${ }^{12}$ show the majority of the D+ILS reoperations/revisions occurred within the first year post-operative associated with "learning curve" issues. The "learning curve" group accounted for 19 of the 35 revisions in the D+ILS group including wound-related issues, re-decompression, and/or poor patient selection/surgical planning. In comparison, 6 of the 19 revisions in the fusion group were early surgical issues. The DF group had a $6.5 \%$ rate of device-related failure requiring revision and 5.6\% late-term (greater than one-year post-operative) ineffective treatment revisions, thereby an effective $12.1 \%$ overall revision rate. In comparison, the D+ILS group had a $2.8 \%$ rate of device-related revisions and 4.2\% late-term ineffective treatment revisions resulting in an effective $7 \%$ overall revision rate at 5 years.

\section{Indications/Limitations of}

\section{Coverage}

Patients who have all of the following criteria may be eligible for decompression with interlaminar stabilization:

1. Radiographic confirmation of at least moderate lumbar stenosis, which narrows the central spinal canal at 1 or 2 contiguous levels from L-1 to L-5 that require surgical decompression. Moderate stenosis is defined as $>25 \%$ reduction of the anteroposterior dimension compared with the next adjacent normal level, with nerve root crowding compared with the normal level, as determined by the surgeon on CT scanning or MRI.

2. Radiographic confirmation of the absence of gross angular or translatory instability of the spine at index or adjacent levels (instability as defined by White and Panjabi: sagittal plane translation $>4.0$ $\mathrm{mm}$ or $15 \%$ or local sagittal plane rotation $>15^{\circ}$ at L1-2, L2-3, and L3-4; > 20 at L4-5 based on standing flexion-extension radiographs). Improved imaging technologies are able to better refine/detect previously undetected instability and as these technologies become more established, surgeons should expect to refine with specificity and clear delineation of appropriate surgical candidates requiring stabilization.

3. Patients who experience relief in flexion from their symptoms of leg/buttocks/groin pain, with or without back pain, and who have undergone at least 12 weeks of non-operative treatment consisting of non-steroidal anti-inflammatory drugs and at least one of the following: rest, restriction of activities of daily living, physical therapy, or steroid injections.

Decompression with interlaminar stabilization is NOT indicated for patients with the following:

1. More than 2 vertebral levels requiring surgical decompression.

2. Prior surgical procedure that resulted in gross translatory instability of the lumbar spine.

3. Prior fusion, implantation of a total disc replacement, or complete laminectomy at index level.

4. Radiographically compromised vertebral bodies at any lumbar level(s) caused by current or past trauma, tumor, or infection.

5. Severe facet hypertrophy requiring extensive bone removal that would cause gross instability.

6. Radiographic confirmation of gross angular or translatory instability of the spine at index or adjacent levels with sagittal plane translation $>4.0 \mathrm{~mm}$ as spondylolisthesis or retrolithesis

7. Isthmic spondylolisthesis or spondylolysis (pars fracture). 
8. Degenerative lumbar scoliosis (Cobb angle $>25^{\circ}$ lumbar segmental).

9. Osteopenia and Osteoporosis.

10. Back or leg pain of unknown etiology.

11. Axial back pain only, with no leg, buttock, or groin pain.

12. Morbid obesity defined as a body mass index $>$ 40.

13. Active or chronic infection-systemic or local.

14. Known history of Paget disease, osteomalacia, or any other metabolic bone disease (excluding osteopenia, which is addressed above).

15. Rheumatoid arthritis or other autoimmune disease requiring chronic steroid use.

16. Active malignancy: a patient with a history of any invasive malignancy (except nonmelanoma skin cancer), unless he/she has been treated with curative intent and there has been no clinical signs or symptoms of the malignancy for at least 5-years. Patients with a primary bony tumor are excluded as well. 17. Known allergy to titanium alloys or magnetic resonance contrast agents.

18. Cauda equina syndrome defined as neural compression causing neurogenic bowel or bladder dysfunction.

\section{Coding}

\section{CPT Codes}

Note: New codes are effective January 1, 2017.

- CPT Code 22867: Insertion of interlaminar/interspinous process stabilization/distraction device, without fusion, including image guidance when performed, with open decompression, lumbar; single level.

- CPT Code 22868: Insertion of interlaminar/interspinous process stabilization/distraction device, without fusion, including image guidance when performed, with open decompression, lumbar; second level (List separately in addition to code for primary procedure).

Prior to January 1, 2017, the following codes may be considered provisionally by the coder:

- CPT Code 63030: Lumbar laminotomy (hemil- aminectomy), 1 interspace.

- CPT Code 63035: Lumbar laminotomy (hemilaminectomy), each additional interspace.

- CPT Code 63047: Lumbar laminectomy, facetectomy and foraminotomy, single vertebral segment.

- CPT Code 63048: Lumbar laminectomy, facetectomy and foraminotomy, each additional segment.

- CPT Code 22899: Unlisted procedure, spine.

- CPT Code 22840: Posterior non-segmental instrumentation.

- CPT Code 0171T: Insertion of posterior spinous process distraction device, lumbar, single level.

- CPT Code 0172T: Insertion of posterior spinous process distraction device, lumbar, each additional level.

\section{Documentation Requirements}

- A complete history and physical documenting spinal stenosis clinically, and radiologically, with progressive clinical symptoms even with documented conservative care.

- Radiographic documentation of canal compromise, with MRI or CT evidence of moderate to severe spinal stenosis at one or two contiguous levels with up to Grade 1 spondylolisthesis.

- A course of conservative treatments that include modification of activities, patient education, physical therapy, injection therapy including epidural steroid injections, and oral medication like steroids and nonsteroidal anti-inflammatory drugs (NSAIDs).

- Symptomatology greater than 12-weeks with doc-

\begin{tabular}{|l|l|}
\hline $\begin{array}{l}\text { Table 1. ICD-10-CM } \\
\text { ICD-10-CM Diag- } \\
\text { nosis Code }\end{array}$ & Code Descriptor \\
\hline $\mathbf{M 4 8 . 0 6}$ & Spinal stenosis, lumbar region \\
\hline $\mathbf{M 9 9 . 2 3}$ & Subluxation stenosis of neural canal of lumbar region \\
\hline $\mathbf{M 9 9 . 3 3}$ & Osseous stenosis of neural canal of lumbar region \\
\hline $\mathbf{M 9 9 . 4 3}$ & $\begin{array}{l}\text { Connective tissue stenosis of neural canal of lumbar re- } \\
\text { gion }\end{array}$ \\
\hline $\mathbf{M 9 9 . 5 3}$ & $\begin{array}{l}\text { Intervertebral disc stenosis of neural canal of lumbar } \\
\text { region }\end{array}$ \\
\hline $\mathbf{M 9 9 . 6 3}$ & $\begin{array}{l}\text { Osseous and subluxation stenosis of intervertebral } \\
\text { foramina of lumbar region }\end{array}$ \\
\hline $\mathbf{M 9 9 . 7 3}$ & $\begin{array}{l}\text { Connective tissue and disc stenosis of intervertebral } \\
\text { foramina of lumbar region }\end{array}$ \\
\hline
\end{tabular}

Downloaded from http://ijssurgery.com/ by guest on April 26, 2023 
umented conservative care, progressive symptomatology, and failure to alleviate symptomatology short of surgical decompression.

\section{Surgeon Qualifications}

Decompression with interlaminar stabilization should only be performed by surgeons who are experienced and have undergone training in the use of this device. Only surgeons who are familiar with the implant components, instruments, procedure, clinical applications, biomechanics, adverse events, and risks associated. A lack of adequate experience and/ or training may lead to a higher incidence of adverse events.

\section{Summary}

Surgeon expertise and proper patient selection are critical to determine the correct surgical treatment solution to address anatomical and pathological variation of patients with LSS. Decompression alone and decompression plus fusion are both established treatments for LSS. The choice to perform decompression alone, decompression with interlaminar stabilization, or decompression plus fusion is the discretionary purview of the spine surgeon and his/her patient.

Lumbar decompression with interlaminar stabiliza- tion is recommended for coverage in carefully selected lumbar spinal stenosis patients without gross instability or in which the decompression procedure itself may create iatrogenic instability. The procedure should be performed by a qualified and well-trained spine surgeon after completion of a thorough diagnostic evaluation, documented failure of nonsurgical management and taking into consideration appropriate anatomical and pathological considerations.

It is important for spine surgeons to be able to provide surgical solutions that have proven net health benefits for clearly defined, precisely diagnosed patient cohorts, which in parallel support fiscal responsibility of reducing overall costs to the healthcare system. Further, in considering the evolutionary healthcare environment, ISASS coverage guidance considers the increasing importance of value-based and bundled payment initiatives which incorporate clinical as well as economic value propositions. In select patients within the LSS continuum, decompression with interlaminar stabilization has proven to provide equivalent outcomes with a reduced cost compared to decompression plus fusion. ${ }^{14,15}$ Additionally, for patients with significant back pain and associated advanced degenerative segmental disease, decompression with interlaminar stabilization provides benefits beyond decompression alone and may extend the durability of the decompression procedure (Table 2). 
Table 2. Publication Table.

\begin{tabular}{|c|c|c|c|c|c|c|c|c|c|}
\hline Author, Year & Study Design & $\begin{array}{l}\text { Country of } \\
\text { Origin }\end{array}$ & $\begin{array}{l}\text { Oxford } \\
\text { Level of } \\
\text { Evidence } \\
\text { (LOE) }\end{array}$ & $\mathrm{N}$ & Implant & Technique & Demographics & Results & Complications \\
\hline $\begin{array}{l}\text { Musacchio, } \\
2016\end{array}$ & $\begin{array}{l}\text { 5- year fol- } \\
\text { low up } \\
\text { Prospective, } \\
\text { multi-center } \\
\text { IDE RCT }\end{array}$ & US & I & 344 & coflex & $\begin{array}{l}\text { Direct decompres- } \\
\text { sion via laminecto- } \\
\text { my w/ subsequent } \\
\text { implantation coflex } \\
\text { ILS OR Decompres- } \\
\text { sion via laminecto- } \\
\text { my w/ subsequent } \\
\text { posterolateral instru- } \\
\text { mented fusion }\end{array}$ & $\begin{array}{l}\text { Age coflex: } 62.1 \\
(41-81) \text { years Age } \\
\text { fusion: } 64.1(41-82) \\
\text { years Sex coflex: } \\
106 \mathrm{~F} / 109 \mathrm{M} \text { Sex fu- } \\
\text { sion: } 58 \mathrm{~F} / 49 \mathrm{M} \\
\text { Moderate-to-severe } \\
\text { lumbar stenosis } \mathrm{w} / \\
\text { back pain ODI } \geq 20 / \\
50(40 \%) \text { VAS } \geq \\
50 / 100\end{array}$ & $\begin{array}{l}5 \text { years, } 50.3 \% \text { of } D+I L S \text { vs. } 44 \% \text { of D+PS patients } \\
(\mathrm{p}>0.35) \text { met the composite success criteria. Reop- } \\
\text { eration/ revision rates were similar in the two } \\
\text { groups }(16.3 \% \text { vs. } 17.8 \% ; p>0.90)\end{array}$ & $\begin{array}{l}\text { There were } 3 / 215 \text { major device related complications in the D+ILS } \\
\text { group and 5/107 in the fusion group at Month } 60(1.4 \% \text { vs. } 4.7 \% \text {; } \\
\text { p }>0.10) ; 60 \text { months: no significant difference in the cumulative total } \\
\text { occurrences of reoperations/revisions between the D+ILS group } 35 / \\
215(16.3 \%) \text { and D+PS group } 19 / 107(17.8 \%)(p>0.90) \text {; wound- } \\
\text { related reoperations: } 7 \text { D+ILS patients }(3.3 \%) \text { and } 1 \text { D+PS patient } \\
(0.09 \%) \text {; under-treated: } 5 \text { D+ILS patients }(2.3 \%) \text { and } 2 \text { D+PS pa- } \\
\text { tients (1.9\%) who underwent early revisions; device-related reoper- } \\
\text { ations: D+ILS group: pars fracture, D+PS group: broken instrumen- } \\
\text { tation; devicerelated reoperations: } 6 \text { patients in the D+ILS (2.8\%) } \\
\text { and } 7 \text { patients in the D+PS group }(6.5 \%)\end{array}$ \\
\hline Forsth, 2016 & RCT & Sweden & I & 247 & N/A & $\begin{array}{l}\text { Decompression with } \\
\text { or without fusion }\end{array}$ & $\begin{array}{l}\text { Age NO DS w/fu- } \\
\text { sion: } 66 \text { (57-75) } \\
\text { years; Age NO DS } \\
\text { w/out fusion: } 66 \\
\text { (58-74); Age +DS } \\
\text { w/ fusion: } 68 \\
\text { (61-75); Age +DS } \\
\text { w/out fusion: } 67 \\
\text { (60-74) years }\end{array}$ & $\begin{array}{l}\text { No significant difference between the groups in the } \\
\text { mean score on the ODI at } 2 \text { years ( } 27 \text { in the fusion } \\
\text { group and } 24 \text { in the decompression-alone group, } \\
\mathrm{P}=0.24 \text { ) or in the results of the } 6 \text {-minute walk test } \\
(397 \mathrm{~m} \text { in the fusion group and } 405 \mathrm{~m} \text { in the } \\
\text { decompression-alone group, } \mathrm{P}=0.72 \text { ) }\end{array}$ & $\begin{array}{l}\text { Dural tears occurred in } 12 \text { patients ( } 11 \% \text { ) in the fusion group and in } \\
13 \text { patients ( } 11 \% \text { ) in the decompression-alone group ; Postoperative } \\
\text { wound infection that required treatment with antibiotic agents but } \\
\text { not reoperation with wound débridement occurred in } 11 \text { patients } \\
(10 \%) \text { in the fusion group and in } 5 \text { patients }(4 \%) \text { in the } \\
\text { decompression-alone group. Myocardial infarction, stroke, or } \\
\text { thromboembolic events occurred in } 3 \text { patients ( } 3 \%) \text { in the fusion } \\
\text { group and in } 5 \text { patients ( } 4 \% \text { ) in the decompression-alone group; ad- } \\
\text { ditional lumbar-spine surgery before the end of October } 2015: 22 \% \\
\text { in the fusion group and } 21 \% \text { in the decompression-alone group }\end{array}$ \\
\hline Bae, 2016 & $\begin{array}{l}\text { 3-year } \\
\text { Follow-up } \\
\text { Prospective, } \\
\text { multicenter } \\
\text { IDE RCT }\end{array}$ & US & I & 344 & coflex & $\begin{array}{l}\text { Direct decompres- } \\
\text { sion via laminecto- } \\
\text { my w/ subsequent } \\
\text { implantation coflex } \\
\text { ILS OR Decompres- } \\
\text { sion via laminecto- } \\
\text { my w/ subsequent } \\
\text { posterolateral instru- } \\
\text { mented fusion }\end{array}$ & $\begin{array}{l}\text { Age coflex: } 62.1 \\
(41-81) \text { years Age } \\
\text { fusion: } 64.1(41-82) \\
\text { years Sex coflex: } \\
106 \mathrm{~F} / 109 \mathrm{M} \text { Sex fu- } \\
\text { sion: } 58 \mathrm{~F} / 49 \mathrm{M} \\
\text { Moderate-to-severe } \\
\text { lumbar stenosis w/ } \\
\text { back pain ODI } \geq 20 / \\
50(40 \%) \mathrm{VAS} \geq \\
50 / 100\end{array}$ & $\begin{array}{l}\text { Composite clinical success at } 36 \text { months was } \\
\text { achieved by } 62.2 \% \text { among } 196 \text { coflex Interlaminar } \\
\text { Stabilization patients and } 48.9 \% \text { among } 94 \text { fusion } \\
\text { patients (difference }=13.3 \%, 95 \% \text { confidence in- } \\
\text { terval, } 1.1 \%-25.5 \%, P=.03 \text { ) }\end{array}$ & $\begin{array}{l}\text { Important harms/severe adverse events that were deemed either def- } \\
\text { initely or probably related to the device occurred in } 19 \text { ILS patients } \\
(8.8 \%) \text { and in } 16 \text { fusion patients }(15 \%) \text { (Fisher exact test, } \mathrm{P}=.13 \text { ). } \\
\text { Important harms that were deemed either definitely or probably re- } \\
\text { lated to the surgery occurred in } 26 \text { ILS patients }(12.1 \%) \text { and } 19 \text { fu- } \\
\text { sion patients }(17.8 \%)(\mathrm{P}=.18) \text {; New or worsening pain at operating } \\
\text { site } 40 \% \text { both groups; nonoperative site events were musculoskele- } \\
\text { tal and neurological events experienced in } 64.2 \% \text { vs } 66.4 \% \text { and } \\
26.0 \% \text { and } 24.3 \% \text { in ILS and fusion patients; } 2 \text { case examples of } \\
\text { spinous process fracture after implantation; reoperation for ILS: } 16 \\
\text { patients with persistent pain with } 7 \text { undergoing reoperation at the in- } \\
\text { dex level alone, } 8 \text { undergoing reoperation at the index level plus } 1 \\
\text { or more adjacent levels, and } 1 \text { undergoing reoperation at an adjacent } \\
\text { level only; } 7 \text { patients with wound issues including } 4 \text { wound infec- } \\
\text { tions, } 2 \text { cerebrospinal fluid leaks, and } 1 \text { wound dehiscence; } 3 \text { pa- } \\
\text { tients with component loosening, and } 4 \text { patients with fractures in- } \\
\text { cluding } 2 \text { spinous process fractures and } 2 \text { pars fractures; reoperation } \\
\text { for fusion: } 9 \text { patients with persistent pain with } 2 \text { patients undergoing } \\
\text { reoperation at the index level alone, } 6 \text { patients undergoing reopera- } \\
\text { tion at the index level plus } 1 \text { or more adjacent levels, and } 1 \text { patient } \\
\text { undergoing reoperation at an adjacent level alone; } 2 \text { patients under- } \\
\text { went reoperation for component failure, including } 1 \text { with a broken } \\
\text { screw and } 1 \text { with screw loosening; } 1 \text { patient underwent reoperation } \\
\text { for a pars fracture at an adjacent level; and } 1 \text { underwent reoperation } \\
\text { for a wound hematoma }\end{array}$ \\
\hline
\end{tabular}




\begin{tabular}{|c|c|c|c|c|c|c|c|c|c|}
\hline Author, Year & Study Design & $\begin{array}{l}\text { Country of } \\
\text { Origin }\end{array}$ & $\begin{array}{l}\text { Oxford } \\
\text { Level of } \\
\text { Evidence } \\
\text { (LOE) }\end{array}$ & $\mathrm{N}$ & Implant & Technique & Demographics & Results & Complications \\
\hline $\begin{array}{l}\text { Sigmundsson, } \\
2016\end{array}$ & $\begin{array}{l}\text { Prospective } \\
\text { register study }\end{array}$ & Sweden & II & 5100 & N/A & $\begin{array}{l}\text { decompression only } \\
\text { OR decompression } \\
\text { with fusion }\end{array}$ & $\begin{array}{l}\text { Age: } 73 \text { years (SD } \\
9.8) ; 49.9 \% \text { male } \\
50.1 \% \text { female } 88 \% \\
\text { decompression on- } \\
\text { ly, } 12 \% \text { decompres- } \\
\text { sion with fusion; } \\
\text { Cohort: operated on } \\
\text { for CSS from Janu- } \\
\text { ary } 2003 \text { to June } \\
2010\end{array}$ & $\begin{array}{l}4167 \text { satisfied patients and } 933 \text { dissatisfied pa- } \\
\text { tients; Factors decreasing the likelihood for satis- } \\
\text { faction included previous spine surgery OR: } 0.4 \\
(95 \% \text { CI: 0.3-0.5), smoking OR: } 0.6 \text { ( } 95 \% \text { CI: } \\
\text { 0.4-0.8), unemployment OR: } 0.6 \text { ( } 95 \% \text { CI: } \\
\text { 0.4-0.9), back pain exceeding } 1 \text { year OR: } 0.6(95 \% \\
\text { CI: } 0.4-0.9 \text { ), back pain predominance OR: } 0.7 \\
(95 \% \text { CI: } 0.5-0.8) \text {. Fusion surgery did not predict } \\
\text { satisfaction OR: } 1.3 \text { (95\% CI: } 0.9-1.9) \text {. Preopera- } \\
\text { tive self-estimated walking distance > } 1000 \text { m pre- } \\
\text { dicted satisfaction, OR: } 2.4 \text { ( } 95 \%: 1.6-3.6) \text {. }\end{array}$ & No complications \\
\hline $\begin{array}{l}\text { Ghogawala, } \\
2016\end{array}$ & $\begin{array}{l}\text { Prospective } \\
\text { RCT }\end{array}$ & US & I & 66 & N/A & $\begin{array}{l}\text { Decompressive } \\
\text { laminectomy with } \\
\text { or without Instru- } \\
\text { mented (rigid pedi- } \\
\text { cle screws affixed to } \\
\text { titanium alloy rods) } \\
\text { lumbar spinal fusion }\end{array}$ & $\begin{array}{l}\text { Age: } 67(50-80) \\
\text { years Grade I lum- } \\
\text { bar spondylolisthe- } \\
\text { sis (degree of } \\
\text { spondylolisthesis, } 3 \\
\text { to } 14 \mathrm{~mm} \text { ) with } \\
\text { lumbar stenosis and } \\
\text { neurogenic claudi- } \\
\text { cation with or with- } \\
\text { out lumbar radicu- } \\
\text { lopathy }\end{array}$ & $\begin{array}{l}\text { Fusion group had a greater increase in SF- } 36 \\
\text { physical-component summary scores at } 2 \text { years af- } \\
\text { ter surgery than did the decompression-alone group } \\
(15.2 \text { vs. } 9.5 \text {, for a difference of } 5.7 ; 95 \% \text { confi- } \\
\text { dence interval, } 0.1 \text { to } 11.3 ; \mathrm{P}=0.046) \text {; fusion group } \\
\text { remained greater at } 3 \text { and } 4 \text { years More blood loss } \\
\text { and longer hospital stays occurred in the fusion } \\
\text { group than in the decompression-alone group } \\
\text { ( } \mathrm{P}<0.001 \text { for both comparisons). The cumulative } \\
\text { rate of reoperation was } 14 \% \text { in the fusion group } \\
\text { and } 34 \% \text { in the decompression-alone group } \\
(\mathrm{P}=0.05) \text {. }\end{array}$ & $\begin{array}{l}\text { Fusion group had a lower rate of reoperation over the course of } 4 \\
\text { years than did the decompression-alone group ( } 14 \% \text { vs. } 34 \% \text {, } \\
\mathrm{P}=0.05) \text {; reoperations performed in the decompression-alone group } \\
\text { were at the index level to address subsequent clinical instability. In } \\
\text { contrast, all the reoperations performed in the fusion group were at } \\
\text { an adjacent lumbar level (either disk herniation or clinical instabili- } \\
\text { ty); surgical complications, blood loss, length of stay, and length of } \\
\text { procedure were significantly greater in the fusion group than in the } \\
\text { decompression-alone group }\end{array}$ \\
\hline Chen, 2016 & $\begin{array}{l}\text { Retrospective } \\
\text { cohort study }\end{array}$ & China & III & 154 & coflex & $\begin{array}{l}\text { Topping-off surgery } \\
\text { (coflex with fusion) } \\
\text { ( } 76 \text { patients) OR } \\
\text { two-segment fusion } \\
\text { surgery (88 patients) }\end{array}$ & $\begin{array}{l}\text { Age: } 40-80 \text { years; } \\
\text { moderate to severe } \\
\text { lumbar spine steno- } \\
\text { sis; unsuccessful } \\
\text { conservative treat- } \\
\text { ment for more than } \\
\text { six months; ODI } \\
\text { score } \geq 40 \text { (out of } \\
100) \text {; VAS for back } \\
\text { pain score } \geq 50 \text { (out } \\
\text { of } 100 \text { ) }\end{array}$ & $\begin{array}{l}\text { Significant differences in clinical outcomes were } \\
\text { observed between these two groups at three post- } \\
\text { operative years (all, } p<0.05 \text { ). Compared with the } \\
\text { fusion group, the topping-off group showed pre- } \\
\text { served mobility at the coflex }{ }^{\mathrm{TM}} \text { level }(\mathrm{p}=0.000) \\
\text { which is associated with less blood loss } \\
(\mathrm{p}=0.000) \text {, shorter duration of surgery }(\mathrm{p}=0.000) \\
\text { and lower incidence of ASD (Chi-square test, rate } \\
\text { topping-off vs fusion }=13.2 \text { vs } 26.1 \%, \mathrm{p}=0.039)\end{array}$ & $\begin{array}{l}\text { No patients in either of the groups had severe intra-operative or } \\
\text { post-operative complications, such as nerve root injury, dural tears, } \\
\text { cauda equina injury, vertebral fracture, internal fixation system frac- } \\
\text { ture, loosened screw, malpositioned screw, dislodgement of the in- } \\
\text { terbody device, fixed wing breakage or spinal process fracture }\end{array}$ \\
\hline Lee, 2016 & $\begin{array}{l}\text { Retrospective } \\
\text { cohort study }\end{array}$ & Korea & III & 30 & coflex & $\begin{array}{l}* * \text { studied erosion } \\
\text { vs. non-erosion after } \\
\text { coflex implant }\end{array}$ & $\begin{array}{l}\text { Age: } 62.2(40-82) \\
\text { M/F ratio: } 15: 15\end{array}$ & $\begin{array}{l}\text { Erosion group showed substantially higher values } \\
\text { in preoperative ADH, postoperative posterior disc } \\
\text { height (PDH), and intervertebral foramen height } \\
(6.52 \mathrm{~mm} \text { vs. } 8.05 \mathrm{~mm} ; 5.80 \mathrm{~mm} \text { vs. } 8.03 \mathrm{~mm} \text {; } \\
19.20 \mathrm{~mm} \text { vs. } 21.06 \mathrm{~mm}) \text {. Postoperative ROM and } \\
\text { ROM ratio were higher in the erosion group }\left(5.95^{\circ}\right. \\
\left.\text { vs. } 8.47^{\circ} \text { and } 0.659 \text { vs. } 0.938\right) .\end{array}$ & $\begin{array}{l}14 \text { patients ( } 47 \% \text { ) showed erosion at the spinous process-coflex in- } \\
\text { terface after surgery }\end{array}$ \\
\hline
\end{tabular}




\begin{tabular}{|c|c|c|c|c|c|c|c|c|c|}
\hline Author, Year & Study Design & $\begin{array}{l}\text { Country of } \\
\text { Origin }\end{array}$ & $\begin{array}{l}\text { Oxford } \\
\text { Level of } \\
\text { Evidence } \\
\text { (LOE) }\end{array}$ & $\mathrm{N}$ & Implant & Technique & Demographics & Results & Complications \\
\hline Bae, 2015 & $\begin{array}{l}\text { Retrospective } \\
\text { analysis of } \\
\text { RCT }\end{array}$ & US & I & 344 & coflex & $\begin{array}{l}\text { Decompression w/ } \\
\text { interlaminar stabi- } \\
\text { lization OR decom- } \\
\text { pression with fusion }\end{array}$ & $\begin{array}{l}230 \text { and } 114 \text { pa- } \\
\text { tients receiving ILS } \\
\text { and fusion respec- } \\
\text { tively during the en- } \\
\text { rollment period } \\
\text { from } 2006 \text { through } \\
2010 \text { at } 21 \text { partici- } \\
\text { pating US sites; } \\
\text { moderate to severe } \\
\text { stenosis, age range } \\
\text { from } 40-80 ; \text { ODI } \\
\text { score } \geq 40 \text { (out of } \\
100 \text { ), VAS for back } \\
\text { pain of } \geq 50 \mathrm{~mm} \\
\text { (out of } 100 \mathrm{~mm} \text { ), } \\
\text { failing } \geq 6 \text { months } \\
\text { of conservative care } \\
\text { including } \geq 1 \\
\text { epidural steroid in- } \\
\text { jection, no prior de- } \\
\text { compression } \\
\text { surgery, up to a } \\
\text { Grade } 1 \text { stable } \\
\text { spondylolisthesis }\end{array}$ & $\begin{array}{l}48 \text { month cumulative rates of index level second } \\
\text { surgeries were } 16.1 \% \text { (SE }=2.6 \% ; 35 / 215) \text { and } \\
14.9 \%(3.6 \% ; 15 / 107) \text { for ILS and fusion, respec- } \\
\text { tively; patients with no index level re-operations or } \\
\text { lumbar steroid injections, } 86.2 \%(106 / 123) \text { of ILS } \\
\text { and } 72.4 \% \text { ( } 42 / 58 \text { ) of fusion subjects had a clini- } \\
\text { cally significant improvement in ODI scores ( } \mathrm{p}= \\
0.038 \text { ) }\end{array}$ & $\begin{array}{l}\text { Through } 48 \text { months, adverse events rates were similar in both co- } \\
\text { horts, although the incidence of events that were deemed 'definitely } \\
\text { or probably related to the implant' occurred in } 14.9 \%(32 / 215) \text { ILS } \\
\text { patients and in } 20.6 \% \text { ( } 22 / 107) \text { of fusion patients ( } \mathrm{p}=0.21) \text {. Events } \\
\text { that were classified as 'severe' occurred in } 8.8 \% \text { of the ILS popula- } \\
\text { tion and } 15.0 \% \text { of the fusion population ( } \mathrm{p}=0.13)\end{array}$ \\
\hline $\begin{array}{l}\text { Sigmundsson, } \\
2015\end{array}$ & $\begin{array}{l}\text { Retrospective } \\
\text { register study }\end{array}$ & Sweden & III & 839 & N/A & $\begin{array}{l}\text { **Compared PLP } \\
\text { and PBP in patients } \\
\text { who got either de- } \\
\text { compression alone } \\
\text { or decompression } \\
\text { with fusion }\end{array}$ & $\begin{array}{l}\text { Age D PLP: 73.8 } \\
\text { (SD 9.3); Age DF } \\
\text { PLP: 68.8 (SD 8.7); } \\
\text { Age D PBP: 73.2 } \\
\text { (SD 10.6); Age DF } \\
\text { PBP: 69.1 (SD 9.1); } \\
\text { Gender: PLP M: D: } \\
\text { 38, DF: 59; F: D: } \\
\text { 87; DF: 200; PBP } \\
\text { M: D: 31; DF: 62; } \\
\text { F: D 89; DF: 270; } \\
\text { older than 50 years } \\
\text { operated for DS at } \\
\text { the L4-L5 level } \\
\text { with either decom- } \\
\text { pression only (D) or } \\
\text { decompression and } \\
\text { instrumented pos- } \\
\text { terolateral fusion } \\
\text { (DF) }\end{array}$ & $\begin{array}{l}\text { Patients with PLP reported a 7.9-mm more im- } \\
\text { provement on the VAS for BP with fusion, com- } \\
\text { pared with D }(95 \% \text { confidence interval [CI], } \\
0.7-15.2), p=.03 \text {; patients with PBP benefited from } \\
\text { adding fusion in terms of BP } 7.1(95 \% \text { CI, } \\
0.3-13.9, p=.04) \text {, LP } 8.8(2-15.7, p=.01) \text {, the ODI } \\
5.7(1.6-9.9, p=.006) \text {, and the EQ-5D } 0.09 \\
(1.7-0.02, p=.02) \text { at the } 1 \text {-year follow-up as the DF } \\
\text { group reported greater change in the outcome com- } \\
\text { pared with the D group }\end{array}$ & No complications \\
\hline
\end{tabular}




\begin{tabular}{|c|c|c|c|c|c|c|c|c|c|}
\hline Author, Year & Study Design & $\begin{array}{l}\text { Country of } \\
\text { Origin }\end{array}$ & $\begin{array}{l}\text { Oxford } \\
\text { Level of } \\
\text { Evidence } \\
\text { (LOE) }\end{array}$ & $\mathrm{N}$ & Implant & Technique & Demographics & Results & Complications \\
\hline Kumar, 2014 & $\begin{array}{l}\text { Prospective } \\
\text { cohort study }\end{array}$ & Singapore & II & 46 & coflex & $\begin{array}{l}\text { Spinal decompres- } \\
\text { sion with coflex im- } \\
\text { plantation vs. de- } \\
\text { compression alone }\end{array}$ & $\begin{array}{l}\text { Symptomatic LSS; } \\
\text { The mean age of the } \\
\text { patients in the } \\
\text { coflex and the com- } \\
\text { parison group was } \\
57.9 \text { years (range, } \\
\text { 40-74 years) and } \\
61.8 \text { years (range, } \\
49-78 \text { years; } \\
\mathrm{p}=0.127) \text {, respec- } \\
\text { tively. The } \\
\text { male:female ratio in } \\
\text { the respective } \\
\text { groups was } 13: 9 \\
\text { (n=22, coflex } \\
\text { group) and } 14: 10 \\
\text { (n=24, comparison } \\
\text { group, } \mathrm{p}=0.958 \text { ). }\end{array}$ & $\begin{array}{l}\text { Mean ODI score in the coflex group improved } \\
\text { from } 51.73 \text { preoperatively to } 22.91,22.64 \text { and } \\
17.36 \text { at six months, one year, and two years; mean } \\
\text { ODI score in the comparison group improved from } \\
49.58 \text { preoperatively to } 32.17,30.08 \text {, and } 28.50 \text { at } \\
\text { six months, one year, and two years; mean differ- } \\
\text { ence in ODI improvement between the two groups } \\
\text { was } 10.4 \text { ( } 95 \% \text { confidence interval [CI], } 8.8-12.1) \text {, } \\
\text { being greater in the coflex group }\end{array}$ & $\begin{array}{l}\text { One patient in the coflex group (dural puncture) and four patients in } \\
\text { the comparison group (3-dural puncture and } 1 \text {-deep infection) had } \\
\text { procedure related complications. The incidence of complications in } \\
\text { the two groups was not significantly different ( } \mathrm{p}=0.35 \text { ) }\end{array}$ \\
\hline Patil, 2014 & $\begin{array}{l}\text { Retrospective } \\
\text { comparative } \\
\text { study }\end{array}$ & US & III & 498 & N/A & $\begin{array}{l}\text { Compare reopera- } \\
\text { tions, complications, } \\
\text { and costs between } \\
\text { LSS patients under- } \\
\text { going ID placement } \\
\text { versus laminectomy }\end{array}$ & $\begin{array}{l}\text { Lumbar spinal } \\
\text { stenosis; Mar- } \\
\text { ketScan database } \\
\text { (2007-2009); age: } \\
73 \text { years }\end{array}$ & $\begin{array}{l}\text { Longer length of stay was observed in the laminec- } \\
\text { tomy cohort ( } 2.5 \text { days vs. } 1.6 \text { days, } p<.0001) \text {, } \\
\text { whereas ID patients accrued higher costs at index } \\
\text { hospitalization }(\$ 17,674 \text { vs. } \$ 12,670, p=.0001) \text {. In- } \\
\text { dex hospitalization }(7.5 \% \text { vs. } 3.5 \% \text {, } p=.099) \text { and } \\
90 \text {-day }(9.2 \% \text { vs. } 3.5 \%, p=.028) \text { complications } \\
\text { were higher in the laminectomy cohort compared } \\
\text { with the ID cohort. The ID patients had significant- } \\
\text { ly higher reoperation rates than laminectomy pa- } \\
\text { tients at } 12 \text { months follow-up }(12.6 \% \text { vs. } 5.8 \% \text {, } \\
p=.026 \text { and incurred higher cumulative costs than } \\
\text { laminectomy patients at } 12 \text { months follow-up } \\
(\$ 39,173 \text { vs. } \$ 34,324, p=.289)\end{array}$ & $\begin{array}{l}\text { Overall reoperation rate was } 22.1 \% \text { for all patients that had an ini- } \\
\text { tial ID placed ; most common type of reoperation was laminectomy } \\
(12.1 \%) \text {, followed by new ID placement }(10.4 \%) \text {, revision inter- } \\
\text { body fusion }(6.0 \%) \text {, and new interbody fusion }(3.6 \%) \text {. Complica- } \\
\text { tions occurred in } 16(3.2 \%) \text { patients at index hospitalization, } 51 \\
(10.2 \%) \text { patients within } 30 \text { days, and in } 51(11.2 \%) \text { patients within } \\
90 \text { days; total of } 348 \text { patients with at least } 18 \text { months follow-up, half } \\
\text { of which underwent direct decompression via laminectomy and the } \\
\text { other half indirect decompression by ID; patients who underwent } \\
\text { laminectomy spent significantly more days at index hospitalization } \\
\text { than patients who underwent ID placement }(2.49 \text { vs. } 1.58, p<.0001)\end{array}$ \\
\hline $\begin{array}{l}\text { Schmier, } \\
2014\end{array}$ & $\begin{array}{l}\text { Retrospective } \\
\text { comparative } \\
\text { cohort }\end{array}$ & US & III & 344 & coflex & $\begin{array}{l}\text { coflex Interlaminar } \\
\text { Stabilization Device } \\
\text { vs. instrumented } \\
\text { posterolateral fusion }\end{array}$ & $\begin{array}{l}\text { Clinical data input } \\
\text { was obtained from } \\
\text { results reported in } \\
\text { Davis et al. that de- } \\
\text { scribe a randomized } \\
\text { Investigational De- } \\
\text { vice Exemption } \\
\text { (IDE) clinical trial } \\
\text { comparing coflex to } \\
\text { instrumented fusion }\end{array}$ & $\begin{array}{l}\text { Five-year costs were lower for patients implanted } \\
\text { with coflex compared to those undergoing fusion. } \\
\text { Average Medicare payments over } 5 \text { years were es- } \\
\text { timated at } \$ 15,182 \text { for coflex compared to } \$ 26,863 \\
\text { for the fusion control, a difference of } \$ 11,681 \text {. } \\
\text { Mean quality-adjusted life years were higher for } \\
\text { coflex patients compared to controls ( } 3.02 \text { vs } 2.97) \text {. } \\
\text { Results indicate that patients implanted with the } \\
\text { coflex device derive more utility, on average, than } \\
\text { those treated with fusion, but at substantially lower } \\
\text { costs }\end{array}$ & No complications \\
\hline
\end{tabular}




\begin{tabular}{|c|c|c|c|c|c|c|c|c|c|}
\hline Author, Year & Study Design & $\begin{array}{l}\text { Country of } \\
\text { Origin }\end{array}$ & $\begin{array}{l}\text { Oxford } \\
\text { Level of } \\
\text { Evidence } \\
\text { (LOE) }\end{array}$ & $\mathrm{N}$ & Implant & Technique & Demographics & Results & Complications \\
\hline Davis, 2013 & $\begin{array}{l}\text { Prospective, } \\
\text { multicenter } \\
\text { IDE RT }\end{array}$ & US & I & 150 & coflex & $\begin{array}{l}\text { coflex Interlaminar } \\
\text { Stabilization OR } \\
\text { laminectomy and } \\
\text { PSF }\end{array}$ & $\begin{array}{l}\text { Only the subset of } \\
\text { patients from this } \\
\text { overall cohort with } \\
\text { Grade } 1 \text { spondy- } \\
\text { lolisthesis ( } 99 \text { in the } \\
\text { coflex group and } 51 \\
\text { in the fusion group); } \\
\text { mean ages of the } \\
\text { coflex and fusion } \\
\text { cohorts were } 63.1 \pm \\
7.9 \text { years and } 65.0 \pm \\
8.5 \text { years; coflex co- } \\
\text { hort, there were } 58 \\
\text { women and } 41 \text { men } \\
\text { compared with } 32 \\
\text { women and } 19 \text { men } \\
\text { in the fusion cohort }\end{array}$ & $\begin{array}{l}\text { ODI: baseline: coflex cohort had an average score } \\
\text { of } 21.1 \text { compared with } 22.7 \text { for fusions }(\mathrm{p}=0.66) \text {; } \\
\text { percentage of patients that achieved a } 15 \text {-point re- } \\
\text { duction in ODI at } 2 \text { years from baseline was } 86.1 \% \\
\text { for coflex and } 81.0 \% \text { for fusion }(\mathrm{p}=0.60) ; \mathrm{ZCQ}: \\
\text { coflex cohort performed significantly better than } \\
\text { fusion controls with respect to } Z C Q \text { patient satis- } \\
\text { faction at } 24 \text { months }(\mathrm{p}=0.05) \text {; } S \mathrm{~S}-12 \text { : no signifi- } \\
\text { cant differences at any pre- or postoperative time } \\
\text { point; } \text { VAS: coflex subjects experienced a } 55 \text {-point } \\
\text { improvement in the back VAS score compared } \\
\text { with } 58 \text { points for fusions }(\mathrm{p}>0.05 \text { ) at } 24 \text { months }\end{array}$ & $\begin{array}{l}\text { Overall rate of operative site AEs between the groups was similar } \\
\text { for coflex }(43.4 \% \text { and fusions }(37.3 \%, \mathrm{p}=0.49) \text {. The rate of severe } \\
\text { adverse events that were definitely or probably related to the im- } \\
\text { plant was } 9.1 \% \text { in the coflex group and } 7.8 \% \text { in the fusion group ( } \mathrm{p} \\
=1.0) \text {. Wound-related problems were seen in } 14.1 \% \text { of coflex pa- } \\
\text { tients compared with } 13.7 \% \text { in the fusion controls }(\mathrm{p}=1.0) \text {. The } \\
\text { rate of spinous process fracture in the coflex cohort was } 18 \% \text { ( } 18 \text { of } \\
99) \text {; however, by } 24 \text { months } 7 \text { of these } 18 \text { fractures had healed; CCS } \\
\text { for patients experiencing a spinous process fracture was } 61.1 \%(11 \\
\text { of } 18) \text {, compared with } 63.2 \% \text { ( } 48 \text { of } 76, \mathrm{p}=1.00) \text { in the cohort } \\
\text { without a fracture; } 6.4 \% \text { of coflex subjects experienced device } \\
\text { movement greater than } 5 \mathrm{~mm} \text { at } 24 \text { months. Wound-related prob- } \\
\text { lems included wound drainage, superficial infection, dehiscence, } \\
\text { seroma, and delayed healing of incision. Only } 1 \text { patient had an irri- } \\
\text { gation and debridement procedure due to wound dehiscence. Within } \\
\text { the fusion control group, a total of } 29 \% \text { ( } 15 \text { of } 51) \text { developed a } \\
\text { pseudarthrosis; overall reoperation rate was } 14.1 \% \text { ( } 14 \text { of } 99) \text { and } \\
5.9 \% \text { ( } 3 \text { of } 51 \text { ) for the coflex and fusion controls, respectively }(\mathrm{p}= \\
0.18)\end{array}$ \\
\hline Davis, 2013 & $\begin{array}{l}\text { Prospective, } \\
\text { multicenter } \\
\text { IDE RT }\end{array}$ & US & I & 322 & coflex & $\begin{array}{l}\text { coflex Interlaminar } \\
\text { Stabilization OR } \\
\text { laminectomy and } \\
\text { PSF }\end{array}$ & $\begin{array}{l}\text { Three hundred } \\
\text { twenty-two patients } \\
(215 \text { coflex and } 107 \\
\text { fusions) from } 21 \\
\text { sites in the United } \\
\text { States were enrolled } \\
\text { between } 2006 \text { and } \\
2010 . ; \text { average age } \\
\text { (standard deviation, } \\
\text { range) for the coflex } \\
\text { cohort was } 62.1 \\
(9.2,41-81) \text { years, } \\
\text { while the average } \\
\text { age for the fusion } \\
\text { control cohort was } \\
64.1(9.0,41-82) \\
\text { years }\end{array}$ & $\begin{array}{l}\text { At } 24 \text { months ODI: coflex: } 22.0 \text {; fusion: } 26.7, \mathrm{P}= \\
0.075 \text {; greater proportion of patients taking coflex } \\
\text { achieving a } 15 \text {-point reduction in ODI at } 24 \\
\text { months (coflex: } 85.8 \% \text {; fusion: } 76.7 \%, \mathrm{P}=0.08 ; 24 \\
\text { months, SF-12 scores had improved significantly } \\
\text { more from baseline in the coflex cohort (15.5 } \\
\text { points) compared with fusion controls (12.6, } \mathrm{P}= \\
0.050) \text {, Significant improvements in the coflex co- } \\
\text { hort compared with fusion controls were also seen } \\
\text { at } 6 \text { weeks }(\mathrm{P}=0.048), 3 \text { months }(\mathrm{P}=0.032) \text {; early } \\
\text { postoperative period: coflex cohort had a trend to- } \\
\text { ward significantly lower VAS back pain scores at } 3 \\
\text { months }(\mathrm{P}=0.062) \text { and } 6 \text { months }(\mathrm{P}=0.063) \text {. VAS } \\
\text { leg pain score was significantly better in the coflex } \\
\text { cohort at } 3 \text { months }(\mathrm{P}=0.019) \text { and a trend at } 6 \\
\text { months }(\mathrm{P}=0.058) \text {; index level range of motion } \\
\text { was maintained with coflex, while fusion subjects } \\
\text { exhibited an expected significant decrease in the } \\
\text { index level range of motion.fusion group demon- } \\
\text { strated significantly greater superior adjacent level } \\
\text { range of motion when compared with coflex }(\mathrm{P}= \\
0.002) ; 24 \text { months, } 135 \text { of } 204 \text { coflex subjects } \\
(66.2 \%) \text { and } 60 \text { of } 104(57.7 \% \text { ) fusion controls met } \\
\text { the criteria for overall study success, demonstrating } \\
\text { noninferiority (posterior probability }=0.999) \text {. }\end{array}$ & $\begin{array}{l}\text { Operative site adverse event: } 49.3 \% \text { coflex vs. } 43.9 \% \text { fusion; ad- } \\
\text { verse event definitely/probably related to the implant: } 13.5 \% \text { coflex } \\
\text { vs. } 18.7 \% \text { fusion; adverse event definitely/probably related to the } \\
\text { surgery: } 23.7 \% \text { coflex vs. } 30.8 \% \text { fusion; rate of spinous process } \\
\text { fracture was } 14.0 \% \text { in the coflex group, however, } 48 \% \text { of these had } \\
\text { healed radiographically at } 2 \text { years; } 0 \text { to } 24 \text { months postoperatively, } \\
\text { the reoperation rate for coflex was } 23 / 215(10.7 \%) \text { compared with } 8 \\
\text { of } 107 \text { for fusion }(7.5 \%, P=0.426) \text {. Among the } 23 \text { patients with re- } \\
\text { operations within the coflex group, there were } 13 \text { conversion to a } \\
\text { primary lumbar fusion, } 6 \text { irrigation and debridements for wound- } \\
\text { related issues ( } 5 \text { with retention of the device), and } 6 \text { revision de- } \\
\text { compressions ( } 4 \text { with device removal) }\end{array}$ \\
\hline
\end{tabular}




\begin{tabular}{|c|c|c|c|c|c|c|c|c|c|}
\hline Author, Year & Study Design & $\begin{array}{l}\text { Country of } \\
\text { Origin }\end{array}$ & $\begin{array}{l}\text { Oxford } \\
\text { Level of } \\
\text { Evidence } \\
\text { (LOE) }\end{array}$ & $\mathrm{N}$ & Implant & Technique & Demographics & Results & Complications \\
\hline Moojen, 2013 & $\begin{array}{l}\text { Prospective, } \\
\text { multicenter } \\
\text { RCT }\end{array}$ & Netherlands & I & 159 & coflex & $\begin{array}{l}\text { Is interspinous } \\
\text { process device im- } \\
\text { plantation more ef- } \\
\text { fective in the short } \\
\text { term than conven- } \\
\text { tional surgical de- } \\
\text { compression for pa- } \\
\text { tients with intermit- } \\
\text { tent neurogenic } \\
\text { claudication due to } \\
\text { lumbar spinal steno- } \\
\text { sis }\end{array}$ & $\begin{array}{l}\text { Patients with inter- } \\
\text { mittent neurogenic } \\
\text { claudication due to } \\
\text { lumbar spinal steno- } \\
\text { sis after failed con- } \\
\text { servative treatment } \\
\text { (Foraminal Enlarge- } \\
\text { ment Lumbar Inter- } \\
\text { spinosus distraXion: } \\
\text { FELIX trial); Age: } \\
40 \text { and } 85 \text { years } \\
\text { with at least three } \\
\text { months of intermit- } \\
\text { tent neurogenic } \\
\text { claudication due to } \\
\text { single or two level } \\
\text { degenerative lumbar } \\
\text { canal stenosis and } \\
\text { an indication for } \\
\text { surgery }\end{array}$ & $\begin{array}{l}\text { Eight weeks, the success rate according to the } \\
\text { Zurich Claudication Questionnaire for the inter- } \\
\text { spinous process device group }(63 \%, 95 \% \text { confi- } \\
\text { dence interval } 51 \% \text { to } 73 \% \text { ) was not superior to } \\
\text { that for standard bony decompression }(72 \%, 60 \% \\
\text { to } 81 \%) \text {; repeat surgery rate in the interspinous im- } \\
\text { plant group was substantially higher }(\mathrm{n}=21 ; 29 \%) \\
\text { than that in the conventional group }(\mathrm{n}=6 ; 8 \%) \text { in } \\
\text { the early post-surgical period }(\mathrm{P}<0.001) ; \text { Surgery } \\
\text { time }(24 \text { min) was shorter in the interspinous } \\
\text { process device group than for bony decompression } \\
(43 \text { min) }(\mathrm{P}<0.001) \text {. Blood loss was less in the in- } \\
\text { terspinous process device group }(10-50 \mathrm{~mL}) \text { than } \\
\text { in the bony decompression group }(50-100 \mathrm{~mL}) \\
(\mathrm{P}<0.001)\end{array}$ & $\begin{array}{l}\text { Five direct (that is, during the initial hospital stay) postoperative } \\
\text { complications occurred in the interspinous process device: one pa- } \\
\text { tient with short term ( } 48 \text { hours) unexplained visual disturbance, one } \\
\text { patient with self limiting pseudoradicular pain in the other leg, and } \\
\text { three patients with interspinous process fractures during inter- } \\
\text { spinous process device placement; Direct postoperative complica- } \\
\text { tions occurred in six patients in the bony decompression group: two } \\
\text { patients with direct epidural hematoma needing reoperation and } \\
\text { four patients with dural tears without further consequences. Late re- } \\
\text { operation due to absence of recovery was indicated and performed } \\
\text { in } 21 / 73(29 \%) \text { cases in the interspinous process device group com- } \\
\text { pared with } 6 / 72(8 \%) \text { in the bony decompression group }(\mathrm{P}<0.001)\end{array}$ \\
\hline Tian, 2013 & $\begin{array}{l}\text { Retrospective } \\
\text { cohort study }\end{array}$ & China & III & 32 & coflex & $\begin{array}{l}\text { Single-level (L4-5) } \\
\text { implantation of a } \\
\text { coflex device for the } \\
\text { treatment of lumbar } \\
\text { spinal stenosis }\end{array}$ & $\begin{array}{l}13 \text { women and } 19 \\
\text { men; age: } 60.3 \\
\text { years (range } 45-75 \\
\text { years); conservative } \\
\text { treatment for at least } \\
3 \text { months had failed; }\end{array}$ & $\begin{array}{l}32 \text { patients with follow-up times of } 24-57 \text { months, } \\
\text { HO was detectable in } 26(81.2 \%) \text {. Among these } 26 \\
\text { patients, HO was in the lateral space of the spinous } \\
\text { process but not in the interspinous space in } 8, \mathrm{HO} \\
\text { was in the interspinous space but did not bridge the } \\
\text { adjacent spinous process in } 16 \text {, and interspinous fu- } \\
\text { sion occurred at the level of the device in } 2\end{array}$ & $\begin{array}{l}\text { No patients needed revision or removal of the implants; no fractures } \\
\text { or loosening of the implant occurred }\end{array}$ \\
\hline $\begin{array}{l}\text { Auerbach, } \\
2013\end{array}$ & $\begin{array}{l}\text { Systematic } \\
\text { review using } \\
\text { Level I data }\end{array}$ & US & $\mathrm{V}$ & $1055 ?$ & coflex & $\begin{array}{l}\text { Investigators for the } \\
\text { coflex IDE trial } \\
\text { classified the severi- } \\
\text { ty of adverse events } \\
\text { (mild, moderate, or } \\
\text { severe) and their re- } \\
\text { lationship to the } \\
\text { surgery and device } \\
\text { (unrelated, unlikely, } \\
\text { possibly, probably, } \\
\text { or definitely). An } \\
\text { independent CEC, } \\
\text { composed of three } \\
\text { spine surgeons with- } \\
\text { out affiliation to the } \\
\text { study sponsor, re- } \\
\text { viewed and reclassi- } \\
\text { fied all adverse } \\
\text { event reports sub- } \\
\text { mitted by the inves- } \\
\text { tigators }\end{array}$ & $\begin{array}{l}\text { independent CEC, } \\
\text { composed of three } \\
\text { spine surgeons } \\
\text { without affiliation } \\
\text { to the study spon- } \\
\text { sor, reviewed and } \\
\text { reclassified all ad- } \\
\text { verse event reports } \\
\text { submitted by the in- } \\
\text { vestigators. }\end{array}$ & $\begin{array}{l}\text { CEC reclassified the level of severity, relation to } \\
\text { the surgery, and/or relation to the device in } 394 \\
(37.3 \%) \text { of } 1055 \text { reported adverse events }\end{array}$ & \\
\hline
\end{tabular}

Downloaded from http://ijssurgery.com/ by guest on April 26, 2023 


\begin{tabular}{|c|c|c|c|c|c|c|c|c|c|}
\hline Author, Year & Study Design & $\begin{array}{l}\text { Country of } \\
\text { Origin }\end{array}$ & $\begin{array}{l}\text { Oxford } \\
\text { Level of } \\
\text { Evidence } \\
\text { (LOE) }\end{array}$ & $\mathrm{N}$ & Implant & Technique & Demographics & Results & Complications \\
\hline Celik, 2012 & $\begin{array}{l}\text { Retrospective } \\
\text { cohort }\end{array}$ & Turkey & III & 20 & coflex & $\begin{array}{l}\text { Microsurgical bilat- } \\
\text { eral foraminotomy; } \\
\text { Co exTM IDD was } \\
\text { placed in inter- } \\
\text { spinous space with } \\
\text { amount of inter- } \\
\text { spinous distraction. }\end{array}$ & $\begin{array}{l}20 \text { patients ( } 9 \text { fe- } \\
\text { male and } 11 \text { male) } \\
\text { with spinal stenosis } \\
\text { were included in the } \\
\text { study. The mean } \\
\text { age was } 60 \text { (range } \\
47-74) \text {. In } 4 \text { pa- } \\
\text { tients, L3-L4 level } \\
\text { and in } 16 \text { patients, } \\
\text { L4-L5 level was im- } \\
\text { planted }\end{array}$ & $\begin{array}{l}\text { Mean preoperative VAS was } 7.85 \text { and fell to } 1.7 \text { a } \\
\text { month after surgery }(\mathrm{p}<0.0001) \text {. At the last } \\
\text { follow-up the mean VAS score was } 1.65(\mathrm{p}< \\
0.0001) \text {. The mean foraminal heights were mea- } \\
\text { sured } 19.95 \mathrm{~mm} \text { preoperatively and } 25.05 \mathrm{~mm} \text { a } \\
\text { month after surgery }(\mathrm{p}<0.0001) \text {. The mean foram- } \\
\text { inal height was } 21.60 \mathrm{~mm} \text { at the last follow-up } \\
(\mathrm{p}=0.002) \text {. The mean lumbar lordosis were mea- } \\
\text { sured } 32.05 \text { and } 34.3 \text { degrees at preoperative and a } \\
\text { month after surgery respectively }(\mathrm{p}=0.155) \text {. The } \\
\text { mean lumbar lordosis was } 32 \text { ( } \pm 5.99) \text { degrees at the } \\
\text { last follow-up ( }=0.974)\end{array}$ & $\begin{array}{l}\text { No major complications occurred; } 1 \text { superficial wound infection } \\
\text { was treated with antibiotics; } 1 \text { dural tear was treated with myofas- } \\
\text { cial flap; No implant-related complication was occurred }\end{array}$ \\
\hline Maida, 2012 & Case report & Italy & IV & 1 & coflex & $\begin{array}{l}\text { Abnormal osseous } \\
\text { tuberosity was sub- } \\
\text { sequently detected } \\
\text { surrounding the L4 } \\
\text { and L5 spinous } \\
\text { processes. The inter- } \\
\text { spinous/interlaminar } \\
\text { coflex device im- } \\
\text { planted at that level } \\
\text { was not detectable; } \\
\text { resect the new bone } \\
\text { formation with a } \\
\text { chisel; "U-shaped" } \\
\text { part of the device } \\
\text { was completely } \\
\text { filled by bone; re- } \\
\text { section of device; } \\
\text { dura mater was all } \\
\text { covered by inter- } \\
\text { laminar bone re- } \\
\text { moved using Kerri- } \\
\text { son rongeurs; gross- } \\
\text { total resection of the } \\
\text { new bone forma- } \\
\text { tion; L4-L5 } \\
\text { laminectomy with } \\
\text { facet joints preser- } \\
\text { vation and L3, S1 } \\
\text { undercutting per- } \\
\text { formed }\end{array}$ & $\begin{array}{l}58 \text { year-old man } \\
\text { presented with a } \\
\text { 6-month history of } \\
\text { progressively wors- } \\
\text { ening low back } \\
\text { pain; VAS: } 8 / 10 ; \\
\text { 2008: microsurgical } \\
\text { decompressive un- } \\
\text { dercutting and im- } \\
\text { plantation of an in- } \\
\text { terspinous/interlam- } \\
\text { inar coflex device } \\
\text { because of L4-L5 } \\
\text { stenosis; 2011: re- } \\
\text { currence of motor } \\
\text { weakness with the } \\
\text { L5 myotome affect- } \\
\text { ed, decreased } \\
\text { Achilles and patel- } \\
\text { lar reflexes, and } \\
\text { neurogenic claudi- } \\
\text { cation; mature ossi- } \\
\text { fication of the de- } \\
\text { vice with relevant } \\
\text { restenosis }\end{array}$ & $\begin{array}{l}\text { Resection of the pathologic bone formation result- } \\
\text { ed in a rapid neurological recovery (VAS } 3 / 10 \text { ), } \\
\text { and the patient could then walk independently; } \\
\text { 2-month followup, the patient had a great reduction } \\
\text { in pain and disability }\end{array}$ & $\begin{array}{l}\text { HO after implantation of an interspinous/interlaminar dynamic de- } \\
\text { vice (case report) }\end{array}$ \\
\hline
\end{tabular}




\begin{tabular}{|c|c|c|c|c|c|c|c|c|c|}
\hline Author, Year & Study Design & $\begin{array}{l}\text { Country of } \\
\text { Origin }\end{array}$ & $\begin{array}{l}\text { Oxford } \\
\text { Level of } \\
\text { Evidence } \\
\text { (LOE) }\end{array}$ & $\mathrm{N}$ & Implant & Technique & Demographics & Results & Complications \\
\hline $\begin{array}{l}\text { Tosteson } \\
2011\end{array}$ & $\begin{array}{l}\text { Cost- } \\
\text { effectiveness } \\
\text { analysis of a } \\
\text { randomized } \\
\text { plus observa- } \\
\text { tional cohort } \\
\text { trial }\end{array}$ & US & I & $? ?$ & & $\begin{array}{l}\text { For SpS, the proto- } \\
\text { col surgical inter- } \\
\text { vention was a stan- } \\
\text { dard posterior } \\
\text { laminectomy. For } \\
\text { DS, the protocol } \\
\text { surgery was the } \\
\text { same procedure } \\
\text { with or without bi- } \\
\text { lateral single-level } \\
\text { fusion with or with- } \\
\text { out instrumentation. } \\
\text { For IDH, the proto- } \\
\text { col surgical inter- } \\
\text { vention was a stan- } \\
\text { dard open discecto- } \\
\text { my }\end{array}$ & $\begin{array}{l}18 \text { and older with } \\
\text { well-defined symp- } \\
\text { toms, physical find- } \\
\text { ings and imaging- } \\
\text { confirmed diagnosis } \\
\text { of spinal stenosis ei- } \\
\text { ther alone (SpS) or } \\
\text { associated with de- } \\
\text { generative spondy- } \\
\text { lolisthesis (DS), or } \\
\text { diagnosis of inter- } \\
\text { vertebral disc herni- } \\
\text { ation (IDH); A total } \\
\text { of } 414 / 634(65.3 \%) \\
\text { SpS, } 391 / 601 \\
\text { (65.1\%) DS and } \\
789 / 1,192(66.2 \%) \\
\text { IDH participants } \\
\text { underwent surgery }\end{array}$ & $\begin{array}{l}\text { SPS QALY gain } 0.22 \text {; } 95 \% \text { confidence interval, } \\
\text { CI: } 0.15,0.34 \text {; DS QALY gain } 0.34,95 \% \text { CI: } 0.30 \text {, } \\
\text { 0.47; and IDH QALY gain } 0.34,95 \% \text { CI: } 0.31 \text {, } \\
0.38 \text {; Costs per QALY gained decreased for SPS } \\
\text { from } \$ 77,600 \text { at } 2 \text { years to } \$ 59,400 \text { ( } 95 \% \text { CI: } \\
\$ 37,059, \$ 125,162) \text { at } 4 \text { years, for DS from } \\
\$ 115,600 \text { to } \$ 64,300 \text { per QALY }(95 \% \text { CI: } \$ 32,864 \text {, } \\
\$ 83,117) \text {, and for IDH from } \$ 34,355 \text { to } \$ 20,600 \\
\text { per QALY }(95 \% \text { CI: } \$ 4,539, \$ 33,088)\end{array}$ & $\begin{array}{l}\text { For SpS, } 43(10.4 \%) \text { patients underwent } 47 \text { additional surgeries; for } \\
\text { DS, } 48(12.3 \%) \text { patients had } 52 \text { additional surgeries, and for IDH } 70 \\
\text { ( } 8.9 \%) \text { patients had } 82 \text { repeat surgeries. In each case, the majority } \\
\text { of repeat surgeries were within } 2 \text { years of the initial surgery with a } \\
\text { substantial minority occurring after } 2 \text { years, including } 32.6 \% \text { of } \\
\text { SpS, } 20.8 \% \text { of DS and } 24.4 \% \text { of IDH repeat procedures }\end{array}$ \\
\hline Richter, 2010 & $\begin{array}{l}\text { Prospective } \\
\text { comparative } \\
\text { study }\end{array}$ & Germany & II & 60 & coflex & $\begin{array}{l}\text { Posterior decom- } \\
\text { pression surgery } \\
\text { through a midline } \\
\text { approach and micro- } \\
\text { surgical bilateral de- } \\
\text { compression with } \\
\text { and without } \\
\text { coflex } \\
\text { spinous inter- } \\
\text { implanted in one or } \\
\text { two levels }\end{array}$ & $\begin{array}{l}\text { Age of } 40-80 \text { with } \\
\text { one or two level } \\
\text { stenosis were in- } \\
\text { cluded and no pre- } \\
\text { vious surgery at the } \\
\text { lumbar spine took } \\
\text { place. Patients with } \\
\text { a stable degenera- } \\
\text { tive spondylolisthe- } \\
\text { sis grade one were } \\
\text { included }\end{array}$ & $\begin{array}{l}\text { All patients increased in function and developed a } \\
\text { lower ODI over time, repeated measure ANOVA } \\
(\mathrm{F}(1)=63.9 ; \mathrm{p}<0.001) ; \text { all patients increased in } \\
\text { function and developed a lower RMS over time, re- } \\
\text { peated measure ANOVA }(\mathrm{F}(1)=24.2 ; \mathrm{p}<0.001) ; \\
\text { all patients had less pain and lower VAS values } \\
\text { over time, repeated measure ANOVA }(\mathrm{F}(1)=50,5 \\
\mathrm{p}<0.001) \text {; all patients had a prolonged WD over } \\
\text { time, repeated measure ANOVA }(\mathrm{F}(1)=33.1 ; \mathrm{p}< \\
0.001)\end{array}$ & $\begin{array}{l}\text { coflex group: one implant-related complication with dislocation of } \\
\text { the implant due to fracture of the spinous process; coflex } \\
\text { two grevisions with pedicle screw fusion of the segment were neces- } \\
\text { sary; undercutting group: one patient had to be instrumented and } \\
\text { fused; both groups we saw one cerebral spinal fluid leak }\end{array}$ \\
\hline $\begin{array}{l}\text { Weinstein } \\
2010\end{array}$ & $\begin{array}{l}\text { Randomized } \\
\text { trial and con- } \\
\text { current ob- } \\
\text { servational } \\
\text { cohort study }\end{array}$ & US & I & $\begin{array}{l}654: \\
289 \\
(\mathrm{RC}) \\
365 \\
(\mathrm{OC})\end{array}$ & & $\begin{array}{l}\text { Standard decom- } \\
\text { pressive laminecto- } \\
\text { my or standard non- } \\
\text { operative care }\end{array}$ & $\begin{array}{l}\text { Surgical candidates } \\
\text { with a history of at } \\
\text { least } 12 \text { weeks of } \\
\text { symptoms and } \\
\text { spinal stenosis with- } \\
\text { out spondylolisthe- } \\
\text { sis (as confirmed on } \\
\text { imaging); Age: ran- } \\
\text { domized: } 65.5 \\
\text { (10.5), observation- } \\
\text { al: } 63.9(12.5)\end{array}$ & $\begin{array}{l}\text { Randomized and observational cohorts' as-treated } \\
\text { treatment effects were similar at } 4 \text { years: Bodily } \\
\text { Pain: RC } 11.4 \text { ( } 95 \% \text { CI, } 5.1 \text { to } 17.6) \text { vs. OC } 14.9 \\
\text { (95\% CI, } 9.3 \text { to } 20.5) \text {, Physical Function: RC } 8.0 \\
(95 \% \text { CI, } 1.7 \text { to } 14.3) \text { vs. OC } 10.1 \text { ( } 95 \% \text { CI, } 4.7 \text { to } \\
\text { 15.5), Oswestry Disability Index: RC }-7.8 \text { (- }-12.9 \text {, } \\
-2.6) \text { vs. OC }-11.5 \text { (- }-15.8,-7.3) \text {; clinically signifi- } \\
\text { cant advantages for surgery previously reported } \\
\text { were maintained through } 4 \text { years, with treatment } \\
\text { effects for BP } 12.6 \text { ( }(95 \% \text { CI, } 8.5 \text { to } 16.7) \text {; PF } 8.6 \\
(95 \% \text { CI, } 4.6 \text { to } 12.6) \text {; and ODI }-9.4 \text { (95\% CI, } \\
-12.6 \text {, to }-6.2)\end{array}$ & $\begin{array}{l}\text { Most common surgical complication was dural tear ( } 9 \%) \text {. The } \\
4 \text {-year reoperation rate was } 13 \% \text {.; Over four years, there were } 12 \\
\text { deaths in the non-operative group within } 4 \text { years of enrollment com- } \\
\text { pared to } 23 \text { expected based on age-gender specific mortality rates, } \\
\text { and } 15 \text { deaths in the surgery group within } 4 \text { years of surgery, com- } \\
\text { pared to } 29 \text { expected; All } 27 \text { deaths were independently reviewed } \\
\text { and } 23 \text { were judged not to be treatment-related. Four deaths were of } \\
\text { unknown cause and unknown treatment relation but occurred } 1203 \text {, } \\
1192,855,501 \text { days post-surgery/enrollment. Three of these deaths } \\
\text { were in patients who had had surgery and one was in a patient who } \\
\text { had not had surgery. }\end{array}$ \\
\hline
\end{tabular}




\begin{tabular}{|c|c|c|c|c|c|c|c|c|c|}
\hline Author, Year & Study Design & $\begin{array}{l}\text { Country of } \\
\text { Origin }\end{array}$ & $\begin{array}{l}\text { Oxford } \\
\text { Level of } \\
\text { Evidence } \\
\text { (LOE) }\end{array}$ & $\mathrm{N}$ & Implant & Technique & Demographics & Results & Complications \\
\hline Kabir, 2010 & $\begin{array}{l}\text { Systematic } \\
\text { review of } \\
\text { Level II and } \\
\text { Level III } \\
\text { study }\end{array}$ & $\begin{array}{l}\text { United } \\
\text { Kingdom }\end{array}$ & III & & & $\begin{array}{l}\text { Evaluate the current } \\
\text { biomechanical and } \\
\text { clinical evidence } \\
\text { available on the use } \\
\text { and effectiveness of } \\
\text { lumbar interspinous } \\
\text { devices and to rec- } \\
\text { ommend indications } \\
\text { for their use }\end{array}$ & $\begin{array}{l}\text { A systematic review } \\
\text { of clinical and bio- } \\
\text { mechanical studies } \\
\text { was done using the } \\
\text { following key } \\
\text { words: interspinous } \\
\text { implants, inter- } \\
\text { spinous devices, in- } \\
\text { terspinous spacers, } \\
\text { dynamic stabiliza- } \\
\text { tion, X-STOP, } \\
\text { coflex, Wallis, DI- } \\
\text { AM. The database } \\
\text { inclusions were } \\
\text { MEDLINE, } \\
\text { CINAHL (Cumula- } \\
\text { tive Index to Nurs- } \\
\text { ing and Allied } \\
\text { Health Literature), } \\
\text { and PubMed }\end{array}$ & $\begin{array}{l}\text { Largest number of studies has been with the X- } \\
\text { STOP device. The biomechanical studies with all } \\
\text { the devices showed that ISPs have a beneficial ef- } \\
\text { fect on the kinematics of the degenerative spine. } \\
\text { Apart from } 2 \text { randomized controlled trials, the oth- } \\
\text { er studies with the X-STOP device were not of } \\
\text { high methodologic quality. Nevertheless, analysis } \\
\text { of these studies showed that X-STOP may improve } \\
\text { outcome when compared to nonoperative treatment } \\
\text { in select group of patients aged } 50 \text { or over, with ra- } \\
\text { diologically confirmed lumbar canal stenosis and } \\
\text { neurogenic claudication, who have improvement of } \\
\text { their symptoms in flexion. Studies on the other de- } \\
\text { vices show satisfactory outcome to varying de- } \\
\text { grees. However, due to small number and poor de- } \\
\text { sign of the studies, it is difficult to clearly define } \\
\text { indications for their use in lumbar degenerative } \\
\text { disease }\end{array}$ & \\
\hline Adelt, 2010 & $\begin{array}{l}\text { Retrospective } \\
\text { cohort }\end{array}$ & Germany & III & & & $\begin{array}{l}\text { STUDY IS IN } \\
\text { GERMAN }\end{array}$ & $\begin{array}{l}\text { Retrospective re- } \\
\text { view of patients } \\
\text { treated with coflex } \\
\text { which match IDE } \\
\text { inclusion/exclusion }\end{array}$ & & \\
\hline Cabraja, 2009 & Case-series & Germany & IV & 143 & & $\begin{array}{l}\text { Percutaneous facet } \\
\text { joint denervation } \\
\text { (PFJD). If pain per- } \\
\text { sisted, they were of- } \\
\text { fered implantation } \\
\text { of an interspinous } \\
\text { device (coflex) and/ } \\
\text { or repeat PFJD }\end{array}$ & $\begin{array}{l}\text { Patients with veri- } \\
\text { fied single level } \\
\text { LFJS at level L4-5; } \\
\text { Forty-one patients } \\
\text { with LFJS at L4-5 } \\
\text { underwent PFJD. } \\
\text { Twenty patients } \\
\text { with persisting pain } \\
\text { underwent a subse- } \\
\text { quent surgery for } \\
\text { implantation of an } \\
\text { interspinous device. } \\
\text { Five patients with } \\
\text { recurrent pain at } \\
\text { 6-12 months opted } \\
\text { for an additional } \\
\text { PFJD }\end{array}$ & $\begin{array}{l}\text { Clinical outcome improved significantly in the sur- } \\
\text { gically treated patients; however, it did not differ } \\
\text { compared with patients receiving PFJD only after } \\
24 \text { months; } 7 \text {-day follow-up: } 40 \text { of } 41 \text { ( } 98 \% \text { ) pa- } \\
\text { tients experienced a relief of back pain greater than } \\
50 \% \text { according to the VAS; } 3 \text { months of follow-up, } \\
\text { only } 18 \text { of } 41 \text { ( } 44 \% \text { ) patients reported of a relief of } \\
\text { back pain greater than } 50 \% \text {; defining success as a } \\
\text { reduction of } 50 \% \text { or more in the ODI and VAS, on- } \\
\text { ly } 9 \text { of the } 20(45 \%) \text { coflex patients were success- } \\
\text { ful on the ODI, and only } 7 \text { of } 20 \text { (35\%) were suc- } \\
\text { cessful on VAS } 2 \text { years after surgery. Using the } \\
\text { criteria of } 50 \% \text { reduction in ODI or VAS, similar } \\
\text { results were found in the non-surgical patients [ } 8 \text { of } \\
21(38 \%) \text { according to ODI and } 8 \text { of } 21(38 \%) \text { ac- } \\
\text { cording to VAS] }\end{array}$ & $\begin{array}{l}\text { Three surgical patients with a secondary poor outcome within } 3 \\
\text { months after implantation of a coflex device received an additional } \\
\text { posterior semi-dynamic stabilization; No surgical- or device-related } \\
\text { complications were observed }\end{array}$ \\
\hline
\end{tabular}




\begin{tabular}{|c|c|c|c|c|c|c|c|c|c|}
\hline Author, Year & Study Design & $\begin{array}{l}\text { Country of } \\
\text { Origin }\end{array}$ & $\begin{array}{l}\text { Oxford } \\
\text { Level of } \\
\text { Evidence } \\
\text { (LOE) }\end{array}$ & $\mathrm{N}$ & Implant & Technique & Demographics & Results & Complications \\
\hline Chung, 2009 & Case-report & Korea & IV & 1 & coflex & $\begin{array}{l}\text { Observed fractures } \\
\text { of bilateral inferior } \\
\text { articular processes } \\
\text { of L4 during opera- } \\
\text { tion. Before revi- } \\
\text { sion, we chose de- } \\
\text { compression level } \\
\text { of spinal stenosis } \\
\text { through selective } \\
\text { root block. After, } \\
\text { she underwent pos- } \\
\text { terior decompres- } \\
\text { sion and posterior } \\
\text { segmental fixation } \\
\text { from L3 to S1 }\end{array}$ & $\begin{array}{l}\text { 64-year-old woman } \\
\text { diagnosis of spinal } \\
\text { stenosis and degen- } \\
\text { erative spondylolis- } \\
\text { thesis at L4-L5; de- } \\
\text { compressive } \\
\text { laminotomy with in- } \\
\text { strumentation of in- } \\
\text { terspinous implant } \\
\text { (coflex); } 6 \text { years lat- } \\
\text { er presented with } \\
\text { low back pain and } \\
\text { radiating pain in left } \\
\text { leg; spinal central } \\
\text { canal and foraminal } \\
\text { narrowing found at } \\
\text { L3-L4, L4-L5, and } \\
\text { L5-S1; bilateral in- } \\
\text { ferior articular } \\
\text { processes of L4; } \\
\text { metallic artifact } \\
\text { showing inter- } \\
\text { spinous implant/ } \\
\text { surrounding fluid } \\
\text { collection; perineur- } \\
\text { al adhesion follow- } \\
\text { ing decompression } \\
\text { on central canal and } \\
\text { neural foramen }\end{array}$ & $\begin{array}{l}\text { Symptoms were relieved after revision; unclear } \\
\text { whether interspinous implant increases the possi- } \\
\text { bility of articular process fracture }\end{array}$ & $\begin{array}{l}\text { (Case report) Case of bilateral stress fractures of lumbar posterior } \\
\text { facet after implantation of interspinous process device; unclear } \\
\text { whether previous interspinous process device may cause bilateral } \\
\text { stress fracture of posterior facet }\end{array}$ \\
\hline $\begin{array}{l}\text { Weinstein } \\
2008\end{array}$ & $\begin{array}{l}\text { Randomized } \\
\text { trial and con- } \\
\text { current ob- } \\
\text { servational } \\
\text { cohort study }\end{array}$ & US & I & $\begin{array}{l}654: \\
289 \\
(\mathrm{RC}) \\
365 \\
(\mathrm{OC})\end{array}$ & & $\begin{array}{l}\text { Standard posterior } \\
\text { decompressive } \\
\text { laminectomy OR } \\
\text { nonsurgical "usual } \\
\text { care:" active physi- } \\
\text { cal therapy, educa- } \\
\text { tion or counseling } \\
\text { with home exercise } \\
\text { instruction, and the } \\
\text { administration of } \\
\text { nonsteroidal antiin- } \\
\text { flammatory drugs, if } \\
\text { tolerated }\end{array}$ & $\begin{array}{l}289 \text { randomized co- } \\
\text { hort; } 365 \text { observa- } \\
\text { tional cohort; RC } \\
138 \text { surgical group, } \\
151 \text { nonsurgical } \\
\text { group; OC: } 219 \text { pa- } \\
\text { tients initially chose } \\
\text { surgery and } 146 \text { pa- } \\
\text { tients initially chose } \\
\text { non-operative care; } \\
\text { Surgical candidates } \\
\text { with a history of at } \\
\text { least } 12 \text { weeks of } \\
\text { symptoms and } \\
\text { spinal stenosis with- } \\
\text { out spondylolisthe- } \\
\text { sis (as confirmed on } \\
\text { imaging); Age: ran- } \\
\text { domized: } 65.5 \\
\text { (10.5), observation- } \\
\text { al: } 63.9 \text { (12.5) }\end{array}$ & 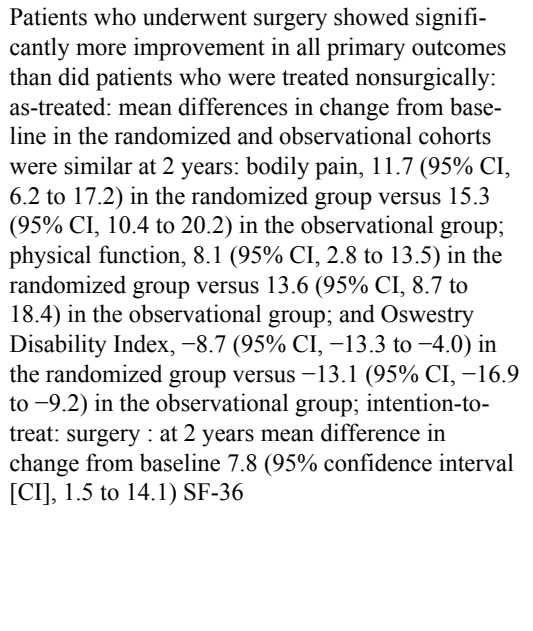 & $\begin{array}{l}10 \% \text { of patients required transfusions intraoperatively and } 5 \% \text { post- } \\
\text { operatively. The most common surgical complication was dural } \\
\text { tear, in } 9 \% \text { of patients. At } 2 \text { years, reoperation had occurred in } 8 \% \\
\text { of patients; fewer than half of these operations were for recurrent } \\
\text { stenosis; At } 2 \text { years, there were seven deaths in the nonsurgical } \\
\text { group and six in the surgical group, one of which occurred within } 3 \\
\text { months after surgery. The deaths were reviewed and } 12 \text { were judged } \\
\text { not to be treatment-related. The one death of unknown cause oc- } \\
\text { curred } 501 \text { days after surgery }\end{array}$ \\
\hline
\end{tabular}

Downloaded from http://ijssurgery.com/ by guest on April 26, 2023 


\begin{tabular}{|c|c|c|c|c|c|c|c|c|c|}
\hline Author, Year & Study Design & $\begin{array}{l}\text { Country of } \\
\text { Origin }\end{array}$ & $\begin{array}{l}\text { Oxford } \\
\text { Level of } \\
\text { Evidence } \\
\text { (LOE) }\end{array}$ & $\mathrm{N}$ & Implant & Technique & Demographics & Results & Complications \\
\hline Kong, 2007 & $\begin{array}{l}\text { Retrospective } \\
\text { cohort study }\end{array}$ & Korea & III & 42 & coflex & $\begin{array}{l}\text { Posterior lumbar in- } \\
\text { terbody fusion } \\
\text { (PLIF) with inter- } \\
\text { body cages: Poly- } \\
\text { ether-ether-ketone } \\
\text { implants or CH } \\
\text { cage, followed by } \\
\text { pedicle screw fixa- } \\
\text { tion OR Foraminal } \\
\text { decompression with } \\
\text { partial laminotomy } \\
\text { w/ coflex implant }\end{array}$ & $\begin{array}{l}\text { Patients having de- } \\
\text { generative spinal } \\
\text { stenosis with mild } \\
\text { segmental instabilit } \\
\text { who underwent im- } \\
\text { plantation of } \\
\text { coflex'M OR PLIF } \\
\text { at L4-5 between } \\
\text { January } 2000 \text { and } \\
\text { December } 2003 \text {; } \\
\text { PLIF: } 24 \text { patients } 8 \\
\text { males and } 16 \text { female } \\
\text { patients who ranged } \\
\text { in age from } 38 \text { to } 78 \\
\text { yr (mean } 56.0 \text { yr) at } \\
\text { the time of surgery; } \\
\text { coflex } \\
\text { patients, } 3 \text { males } 18 \\
\text { and } 15 \text { females, } \\
\text { who ranged in age } \\
\text { from } 40 \text { to } 71 \text { yr } \\
\text { (mean } 61.7 \mathrm{yr} \text { ) }\end{array}$ & $\begin{array}{l}\text { Significant improvement in the VAS and ODI } \\
\text { scores for lower leg pain and low back pain in both } \\
\text { groups ( }<0.05 \text { ), no difference in outcome between } \\
\text { two groups;coflex } \\
\text { radiographs increased significantly from preopera- } \\
\text { tive } 7.8 \mathrm{~mm} \text { to postoperative } 9.1 \mathrm{~mm}(\mathrm{p}<0.05) \text {, } \\
\text { whereas in the PLIF group, the PDH was deter- } \\
\text { mined according to the inserted cage size }(9-14 \\
\mathrm{mm} \text { ); ROM at the upper adjacent segment (L3-4) } \\
\text { in the PLIF group increased significantly after } \\
\text { surgery (p<0.05), whereas the ROM in the } \\
\text { coflex }^{\mathrm{TM}} \text { group did not increase at this level }\end{array}$ & No surgical complication in either groups \\
\hline
\end{tabular}




\section{References}

1. Patel VV, Whang PG, Haley TR, et al. Superion interspinous process spacer for intermittent neurogenic claudication secondary to moderate lumbar spinal stenosis: Two-year results from a randomized controlled FDA-IDE pivotal trial. Spine (Phila Pa 1976). 2015;40(5):275-282.

2. Zucherman JF, Hsu KY, Hartjen CA, et al. A multicenter, prospective, randomized trial evaluating the X STOP interspinous process decompression system for the treatment of neurogenic intermittent claudication: Two-year follow-up results. Spine (Phila Pa 1976). 2005;30(12):1351-1358.

3. Patel VV, Whang PG, Haley TR, et al. Two-year clinical outcomes of a multicenter randomized controlled trial comparing two interspinous spacers for treatment of moderate lumbar spinal stenosis. $B M C$ Musculoskelet Disord. 2014;15:221-2474-15-221.

4. Barbagallo GM, Olindo G, Corbino L, Albanese $\mathrm{V}$. Analysis of complications in patients treated with the $\mathrm{X}$-stop interspinous process decompression system: Proposal for a novel anatomic scoring system for patient selection and review of the literature. Neurosurgery. 2009;65(1):111-19; discussion 119-20.

5. Modhia U, Takemoto S, Braid-Forbes MJ, Weber M, Berven SH. Readmission rates after decompression surgery in patients with lumbar spinal stenosis among medicare beneficiaries. Spine (Phila Pa 1976). 2013;38(7):591-596.

6. Weinstein JN, Tosteson TD, Lurie JD, et al. Surgical versus nonoperative treatment for lumbar spinal stenosis four-year results of the spine patient outcomes research trial. Spine (Phila Pa 1976). 2010;35(14):1329-1338.

7. Weinstein JN, Tosteson TD, Lurie JD, et al. Surgical versus nonsurgical therapy for lumbar spinal stenosis. NEngl J Med. 2008;358(8):794-810.

8. Forsth P, Olafsson G, Carlsson T, et al. A randomized, controlled trial of fusion surgery for lumbar spinal stenosis. $N$ Engl J Med.

2016;374(15):1413-1423.

9. Ghogawala Z, Dziura J, Butler WE, et al. Laminectomy plus fusion versus laminectomy alone for lumbar spondylolisthesis. $N$ Engl J Med. 2016;374(15):1424-1434.
10. Kleinstuck FS, Grob D, Lattig F, et al. The influence of preoperative back pain on the outcome of lumbar decompression surgery. Spine (Phila Pa 1976). 2009;34(11):1198-1203.

11. Kumar N, Shah SM, Ng YH, Pannierselvam VK, Dasde S, Shen L. Role of coflex as an adjunct to decompression for symptomatic lumbar spinal stenosis. Asian Spine J. 2014;8(2):161-169.

12. Musacchio MJ, Lauryssen C, Davis RJ, et al. Evaluation of decompression and interlaminar stabilization compared with decompression and fusion for the treatment of lumbar spinal stenosis: 5-year follow-up of a prospective, randomized, controlled trial. Int J Spine Surg. 2016;10:6.

13. Rauschmann M, Adelt D, Franke J, Schmidt $S$, Sola S, Maislin G, Davis R. Prospective, Randomized Trial Comparing Lumbar Decompression with or without Interlaminar Stabilization with 24 Month Follow-up. In: Proceedings of the 16th Annual Meeting of the International Society for the Advancement of Spine Surgery; 2016 Apr 6-9; Las Vegas, NV, Abstract \#632.

14. Blumen HE, et al. (2015, October 13) Utilization and cost of surgery for lumbar spinal stenosis in a commercially insured population. Retrieved from http://us.milliman.com/insight/2015/Utilizationand-cost-of-surgery-for-lumbar-spinal-stenosis-in-acommercially-insured-population.

15. Schmier JK, Halevi M, Maislin G, Ong K. Comparative cost effectiveness of coflex $(R)$ interlaminar stabilization versus instrumented posterolateral lumbar fusion for the treatment of lumbar spinal stenosis and spondylolisthesis. Clinicoecon Outcomes Res. 2014;6:125-131.

16. Bae HW, Davis RJ, Lauryssen C, Leary S, Maislin G, Musacchio MJ,Jr. Three-year follow-up of the prospective, randomized, controlled trial of coflex interlaminar stabilization vs instrumented fusion in patients with lumbar stenosis. Neurosurgery.

2016;79(2):169-181.

17. Sigmundsson FG, Jonsson B, Stromqvist B. Determinants of patient satisfaction after surgery for central spinal stenosis without concomitant spondylolisthesis: A register study of 5100 patients. Eur Spine J. 2016.

18. Chen XL, Guan L, Liu YZ, Yang JC, Wang WL, Hai Y. Interspinous dynamic stabilization adjacent to 
fusion versus double-segment fusion for treatment of lumbar degenerative disease with a minimum followup of three years. Int Orthop. 2016;40(6):1275-1283. 19. Lee N, Shin DA, Kim KN, et al. Paradoxical radiographic changes of coflex interspinous device with minimum 2-year follow-up in lumbar spinal stenosis. World Neurosurg. 2016;85:177-184.

20. Bae HW, Lauryssen C, Maislin G, Leary S, Musacchio MJ, Jr. Therapeutic sustainability and durability of coflex interlaminar stabilization after decompression for lumbar spinal stenosis: A four year assessment. Int J Spine Surg. 2015;9:15.

21. Sigmundsson FG, Jonsson B, Stromqvist B. Outcome of decompression with and without fusion in spinal stenosis with degenerative spondylolisthesis in relation to preoperative pain pattern: A register study of 1,624 patients. Spine J. 2015;15(4):638-646. 22. Patil CG, Sarmiento JM, Ugiliweneza B, et al. Interspinous device versus laminectomy for lumbar spinal stenosis: A comparative effectiveness study. Spine J. 2014;14(8):1484-1492.

23. Davis R, Auerbach JD, Bae H, Errico TJ. Can low-grade spondylolisthesis be effectively treated by either coflex interlaminar stabilization or laminectomy and posterior spinal fusion? Two-year clinical and radiographic results from the randomized, prospective, multicenter US investigational device exemption trial: Clinical article. J Neurosurg Spine. 2013;19(2):174-184.

24. Davis RJ, Errico TJ, Bae H, Auerbach JD. Decompression and coflex interlaminar stabilization compared with decompression and instrumented spinal fusion for spinal stenosis and low-grade degenerative spondylolisthesis: Two-year results from the prospective, randomized, multicenter, food and drug administration investigational device exemption trial. Spine (Phila Pa 1976). 2013;38(18):1529-1539.

25. Moojen WA, Arts MP, Jacobs WC, et al. Interspinous process device versus standard conventional surgical decompression for lumbar spinal stenosis: Randomized controlled trial. BMJ. 2013;347:f6415. 26. Tian NF, Wu AM, Wu LJ, et al. Incidence of heterotopic ossification after implantation of interspinous process devices. Neurosurg Focus. 2013;35(2):E3.

27. Celik H, Derincek A, Koksal I. Surgical treatment of the spinal stenosis with an interspinous dis- traction device: Do we really restore the foraminal height? Turk Neurosurg. 2012;22(1):50-54.

28. Maida G, Marcati E, Sarubbo S. Heterotopic ossification in vertebral interlaminar/interspinous instrumentation: Report of a case. Case Rep Surg. 2012;2012:970642.

29. Tosteson AN, Tosteson TD, Lurie JD, et al. Comparative effectiveness evidence from the spine patient outcomes research trial: Surgical versus nonoperative care for spinal stenosis, degenerative spondylolisthesis, and intervertebral disc herniation. Spine (Phila Pa 1976). 2011;36(24):2061-2068. 30. Richter A, Schutz C, Hauck M, Halm H. Does an interspinous device (coflex) improve the outcome of decompressive surgery in lumbar spinal stenosis? one-year follow up of a prospective case control study of 60 patients. Eur Spine J.

2010;19(2):283-289.

31. Kabir SM, Gupta SR, Casey AT. Lumbar interspinous spacers: A systematic review of clinical and biomechanical evidence. Spine (Phila Pa 1976). 2010;35(25):E1499-506.

32. Adelt $\mathrm{D}$. The interspinous $\mathrm{U}$ implant (now coflex): Long-term outcome, study overview and differential indication. Orthopade. 2010;39(6):595-601. 33. Cabraja M, Abbushi A, Woiciechowsky C, Kroppenstedt $S$. The short- and mid-term effect of dynamic interspinous distraction in the treatment of recurrent lumbar facet joint pain. Eur Spine J. 2009;18(11):1686-1694.

34. Chung KJ, Hwang YS, Koh SH. Stress fracture of bilateral posterior facet after insertion of interspinous implant. Spine (Phila Pa 1976). 2009;34(10):E380-3.

35. Kong DS, Kim ES, Eoh W. One-year outcome evaluation after interspinous implantation for degenerative spinal stenosis with segmental instability. $J$ Korean Med Sci. 2007;22(2):330-335.

36. Auerbach JD, McGowan KB, Halevi M, et al. Mitigating adverse event reporting bias in spine surgery. J Bone Joint Surg Am. 2013;95(16):1450-1456.

37. Deyo RA, Ciol MA, Cherkin DC, Loeser JD, Bigos SJ. Lumbar spinal fusion. A cohort study of complications, reoperations, and resource use in the medicare population. Spine (Phila Pa 1976).

1993;18(11):1463-1470. 
38. Deyo RA, Mirza SK, Martin BI, Kreuter W, Goodman DC, Jarvik JG. Trends, major medical complications, and charges associated with surgery for lumbar spinal stenosis in older adults. JAMA. 2010;303(13):1259-1265.

39. Martin BI, Mirza SK, Comstock BA, Gray DT, Kreuter W, Deyo RA. Are lumbar spine reoperation rates falling with greater use of fusion surgery and new surgical technology? Spine (Phila Pa 1976). 2007;32(19):2119-2126.

40. Sears W, Maislin G, Davis R, Auerbach J, Errico T, Bae H. Lumbar Spinal Fusion as a Risk Factor for Adjacent Segment Degeneration - Results of a Secondary Analysis of Data from a Clinical, Multicenter, Randomized Controlled Trial. In: Proceedings of the 16th Annual Meeting of the International Society for the Advancement of Spine Surgery; 2016 Apr 6-9; Las Vegas, NV, Abstract \#497.

\section{Disclosures}

Richard Guyer, MD reports serving as a one-day
Faculty Trainer for Paradigm Spine. Frank P. Cammisa, Jr., MD reports investments in Paradigm Spine. Michael Musacchio, MD reports consulting fees and speaking honoraria from Paradigm Spine and Medtronic LLC. Morgan P. Lorio, MD, FACS reports no disclosures.

\section{Corresponding Author}

Richard Guyer, MD, Texas Back Institute, $6020 \mathrm{~W}$. Parker Rd., \#200, Plano, TX 75093. rguyer@texasback.com.

Published 5 December 2016.

This manuscript is generously published free of charge by ISASS, the International Society for the Advancement of Spine Surgery. Copyright @ 2016 ISASS. To see more or order reprints or permissions, see http://ijssurgery.com. 